\title{
ATEÍSMO, RAZÃO E HISTÓRIA: A CRÍTICA DE PIERRE BAYLE AO CONSENSUS UNIVERSALIS*
}

Atheism, reason and history: the Pierre Bayle's consensus universalis critical

\author{
Marcelo de Sant'Anna Alves Primo**
}

Resumo: No presente artigo, trataremos de expor e analisar a reflexão e crítica de Pierre Bayle ao fenômeno da opinião. Segundo o filósofo francês, o maior perigo de depositar demasiada confiança em determinadas proposições acerca de questões polêmicas é que opiniões são adotadas e disseminadas sem que passem por um critério de examen, o qual é alicerçado tanto na experiência como em sólidas razões. Falsas opiniões passadas de geração a geração são o motivo tanto do engrandecimento como do fortalecimento de pseudoautoridades, as quais, dispensando o difícil trabalho do exame de suas considerações, se limitam a critérios quantitativos. Opondo-se radicalmente ao fenômeno da pluralité des voix e à sua utilização como criterium veritatis das opiniões, Bayle afirma a filosofia associandoa à noção de exame, isto é, como um instrumento crítico que passará em revista todas as opiniões e seus argumentos pró e contra, por meio da razão e da história.

Palavras-chave: Bayle. Ateísmo. Crítica. Razão. História.

\begin{abstract}
In this article, we expose and analyze the reflection and critique of Pierre Bayle to the phenomenon of opinion. According to the French philosopher, the greatest danger of placing too much trust in certain propositions about controversial issues is that opinions are adopted and disseminated without passing through a criterion of examen, which is grounded both in experience and in solid reasons. False opinions passed from generation to generation are the reason both of aggrandizement as the strengthening of pseudo-authorities, which, eliminating the hard physical labor of his remarks, merely quantitative criteria. Opposing radically the phenomenon of pluralité des voix and their use as criterium veritatis of opinions, Bayle says philosophy associating it with the notion of assessment, that is, as a critical tool that will review all opinions and their arguments for and against, by means of reason and history.
\end{abstract}

Keywords: Bayle. Atheism. Critical. Reason. history.

\footnotetext{
* As siglas das obras de Pierre Bayle são as seguintes: OD = Oeuvres Diverses; PD = Pensées Diverses sur la comète $\mathrm{CPD}=$ Continuation des Pensées Diverses; $\mathrm{APD}=$ Adittion aux Pensées Diverses $\mathrm{CPh}=\mathrm{Commentaire}$ Philosophique, $\mathrm{SCph}=$ Supplément au Commentaire Philosophique e ESA = Éclaircissement sur les athées. ** Pós-doutorando em filosofia pela Universidade Federal de Sergipe (UFS). Bolsista PNPD/CAPES. Contato : marceloprimo_sp@hotmail.com
}

\begin{tabular}{|c|c|l|l|c|c|}
\hline intuitio & $\begin{array}{c}\text { ISSN } \\
1983-4012\end{array}$ & Porto Alegre & Vol.7- $\mathrm{N}^{\mathrm{o}} .2$ & $\begin{array}{c}\text { Novembro } \\
2014\end{array}$ & p. 172-183 \\
\hline
\end{tabular}


"Mas nem por isso deve alguém tomar esta anuência popular comuníssima como argumento da verdade daquilo que é afirmado. Porque, se interrogarmos os mesmos homens sobre as causas e os motivos pelos quais eles creem assim, e, ao contrário, escutarmos quais experiências e demonstrações induzem aqueles outros poucos a crer o contrário, verificaremos que estes são persuadidos por razões firmíssimas e aqueles por aparências muitíssimo ingênuas e comparações vãs e ridículas."

Galileu Galilei, Ciência e fé.

A opinião - do grego doxa - é, por definição, um estado de espírito designado como pensamento de que uma asserção seja verdadeira, mas podendo estar sujeita a equívocos uma vez que é instituída e propagada por toda uma sociedade, adquirindo o status quo de verdade. ${ }^{1}$ Opinião pública é o juízo coletivo proferido por uma sociedade acerca de um fato ou de uma crença, porém, sem exame prévio. ${ }^{2}$ Mas o que seria a opinião para o próprio Bayle? Para o filósofo francês, opinião é o ponto de vista da tradição, porém, não sustentado em exames, razões e fatos, mas justamente na ausência de todos esses fatores, pautando-se em preconceitos e afirmações temerárias. Segundo Bayle, acomodar-se em vez de se debruçar sobre cada minúcia de uma questão é o procedimento clássico de quem não aceita explicações mais consistentes:

\footnotetext{
${ }^{1}$ N'A República, por exemplo, Platão estabelece pelo menos três sentidos diferentes para o vocábulo doxa: 1 ) distingue o conhecimento (èpistème) da opinião (doxa), sendo esta todo e qualquer julgamento baseado nas aparências V, 476d, p. 216, 477b, p. 217, e VI, 490b, p. 233) sendo o filodoxo (philodoxos), isto é, amante da opinião, oposto ao filósofo (philosophos) amante da sabedoria (V, 480a, p. 222, n. 61.) ; 2) a doxa como "opinião verdadeira" ou "reta" (doxa òrté) mas mesmo assim Platão a ainda a atribui à esfera da sensibilidade (VI, 506c, p. 254 e X, 602a, p. 386); 3) doxa como reputação, isto é, quando Sócrates faz o elogio da justiça como um bem em si mesmo, define-a como um bem do qual o homem tira proveito de sua reputação. (II, 367e, p. 73, n. 20) Todas as referências eu extraí de PLATÃO. A República. Trad. e org. de J. Guinsburg. São Paulo: Perspectiva, 2006 (Textos; 19).

${ }^{2}$ Ver a respeito Bertrand Binoche, "Croyances privées, opinion publique", In: Revue Philosophique de Louvain. Louvain: 2010, p. 617-638. A tese do autor é que a opinião se tornou pública porque a religião se tornou algo do âmbito privado e, para aperceber-se desse fenômeno, é preciso ter em mente duas coisas: 1) que a opinião pública obteve êxito tão e somente devido a ser entendida como uma solução de um determinado problema, que consistiria em uma pacificação social desvinculada de qualquer compromisso doutrinário; 2) por outro lado, ela correria o risco de não corresponder às expectativas, não passando de uma versão secularizada da crença pública, como o catolicismo, por exemplo (p.617-618). Mais além, o autor afirma que, confrontando-se, sob determinadas regras, com as opiniões individuais contraditórias, visando a arranjá-las em uma "aproximação democrática da verdade", a opinião ficaria destituída de sentido perante a uma volatilização permanente". Em outros termos, de acordo com essas mesmas regras, as próprias opiniões, contrárias umas às outras, tornar-se-ão pueris. (p.632). Binoche menciona que, se esses equívocos da opinião pública podem levar um indivíduo a renunciá-la, basta entrevê-la de um outro modo: entendendo-a como uma reflexão coletiva, retirando dela tudo que há de dogmático, separando de toda crença as regras formais que a moldam. (p. 634) Contudo, parece que o autor não consegue dissociar ainda opinião - privada ou pública - de crença, mas no máximo, entende que é preciso aprender a discernir a racionalidade que há na mesma, e a tarefa do filósofo nessa empreitada é a de ser um "hermeneuta do preconceito"(p.634). Em outras palavras, Binoche está nos antípodas das teses de Bayle, na medida em que afirma que a crença é indispensável a qualquer sociedade: "A opinião pública, se podemos ainda nomeá-la assim é, então, o todo de crenças as quais nenhuma comunidade pode dispensar-se e, então, trata-se de discernir respeitosamente a racionalidade: desse fato, não é questão de transformar o mundo, mas de bem interpretá-lo!". (BINOCHE, B. “Croyances privées, opinion publique”, In: Revue Philosophique de Louvain. Louvain: 2010, p. 617-638.)
}

\begin{tabular}{|c|c|c|c|c|c|}
\hline intuitio & $\begin{array}{c}\text { ISSN } \\
1983-4012\end{array}$ & Porto Alegre & Vol.7- $\mathrm{N}^{\circ} .2$ & $\begin{array}{c}\text { Novembro } \\
2014\end{array}$ & p. 172-183 \\
\hline
\end{tabular}


É um método muito fácil de refutar as inovações: evita-se o detalhe das controvérsias; a via da prescrição evita todas as fatigas do exame: porque se dispensam as discussões, a respeito mesmo do ponto de fato sobre a antiguidade e a extensão pressupostas. Reporta-se plenamente à voz pública. Tudo isso lisonjeia a preguiça humana. É por isto que se munem desse argumento em todas as ocasiões, e para uma vez que ele possa ser útil à verdade, é cem vezes favorável à falsidade. ${ }^{3}$

Segundo Bayle, para aderir a uma posição, são necessários critérios rigorosos: a exigência de avaliar o peso dos argumentos e não levar em consideração somente a quantidade de pessoas que os adotam é fator imprescindível em uma discussão polêmica. Ponto fundamental: o filósofo francês aponta para o pleno direito de examinar os prós e contras de uma contenda, e da mesma forma, o pleno direito de aderir a um dos lados, uma vez averiguada a consistência dos argumentos. Em outros termos, Bayle entende que para se aderir ou não à pluralité des voix é preciso pesar as suas razões e não simplesmente quantificá-la:

E daí eu tiro essa consequência que a pluralidade de vozes não é de modo algum aqui uma prova decisiva: cada um pode dispensar-se de aí ter consideração e se manter em um pleno direito de examinar as razões dos dois partidos, e de adotar ou o pequeno número ou o grande número segundo o peso das razões. É o que se chama pesar as vozes e não contá-las. ${ }^{4}$

É nos meandros de tal definição da opinião que a crítica de Bayle vai operar, uma vez que a pluralidade das vozes não passa de um embuste amparado fragilmente em critérios infundados e arbitrários, apoiados na eloquência que "dão mais honra àquele que os debita e muito mais impressão sobre a consciência dos auditores do que cem outras proposições provadas demonstrativamente." ${ }^{.5}$ Na passagem citada, Bayle afirma que todo discurso visando a ganhar muitos adeptos sempre vem acompanhado, ao mesmo tempo, de uma pompa nas palavras e a necessidade imperiosa de causar impacto no público ao qual se dirige. Privilegiando-se a eloqüência, as provas concretas do que está sendo proferido caem no esquecimento, tornando-se mesmo dispensáveis seja da parte do locutor, seja da parte do interlocutor. Nesse sentido, o alvo da crítica do pensador de Carla é específico: a autoridade da tradição. Mas qual tradição? Sejam teólogos, filósofos, físicos, astrônomos, astrólogos

\footnotetext{
${ }^{3} O D$ III $[C P D]$, p. $232 a$. No original: "C'est une méthode très-aisée de refuter les innovations: on évite le détail des controverses; la voie de prescription épargne toutes les fatigues de l'examen: car on se dispense des discussions, à l'égard même du point de fait sur l'antiquité \& l'étendue présupposées: on s'en rapporte pleinement à la voix publique. Tout cela flatte beaucoup la paresse humaine. C'est pourquoi l'on se munit de cet argument dans toutes les occasions, \& pour une fois qu'il peut être utile à la vérité, il est cent fois favorable à la fausseté."

${ }^{4} O D$ III $[C P D]$, p. $231 b$. No original: "Et de là je tire cette conséquence que la pluralité des voix n'est point ici une preuve décisive: chacun se peut dispenser d'y avoir égard, \& se maintenit dans un plein droit d'examiner les raisons des deux partis, \& de se ranger ou au petit nombre des deux partis ou au grand nombre selon le poids des raisons.C'est ce qu'on appelle peser les voix \& non les compter." Ver também o emprego da mesma expressão nos parágrafos $\S \S X X I I-X X X I I I$ e XL.

${ }^{5} P D, 2007$, p. $67 ; O D$ III $[P D]$, p. $10 a$. No original: "Si vous étiez predicateur, je vous pardonnerais parce que ces sortes de pensées, étant naturellement fort propres à être revêtues des plus pompeux et des plus pathétiques ornements de l'éloquence, font beaucoup plus d'honneur à celui qui os débite et beaucoup 'plus d'impression sur la conscience des auditeurs que cent autres propositions prouvées demonstrativement."
}

\begin{tabular}{|c|c|l|l|c|c|}
\hline intuitio & $\begin{array}{c}\text { ISSN } \\
1983-4012\end{array}$ & Porto Alegre & Vol.7- $\mathrm{N}^{\circ} .2$ & $\begin{array}{c}\text { Novembro } \\
2014\end{array}$ & p. 172-183 \\
\hline
\end{tabular}


ou historiadores $^{6}$ : todos eles, a seu ver, ainda estão reduzidos a esse lugar comum, isto é, estão presos à opinião corriqueira e de tempos imemoriais de que fenômenos naturais são avisos celestes de mau agouro para o porvir. $^{7}$ A associação é clara entre a tradição e seu psicologismo de cunho instrumentalista, uma vez que discurso algum é despretensioso e sempre visa a ser disseminado no círculo social. Segundo Isabelle Delpla, "esta gênese psicológica da autoridade social além de toda legitimidade está igualmente na origem da autoridade da tradição. Bayle descreve um fenômeno mecânico e quase epidêmico de propagação da opinião, seja ela falsa." ${ }^{8}$

Bayle afirma categoricamente: "Que não podemos ver o que se passa no espírito dos homens quando eles escolhem uma opinião!"9 Tal exclamação pode ser fundada sobre diversos fatores que levam os homens a aderirem cegamente a um ponto de vista, como, por exemplo, preguiça, preconceito, credulidade, conformismo, docilidade e outros empecilhos à reflexão, e o resultado direto disso seria um "delírio interpretativo" $" 10$ fazendo com que se vejam signos em todos os lugares. Nesse contexto, uma opinião falsa passa facilmente por verdadeira, tornando-se parte constitutiva de uma determinada sociedade. O erro torna-se uma realidade social e política, a última palavra de um todo que se reconhece pela adesão a uma opinião destituída de qualquer fundamentação, elevando a tradição à condição de autoridade e imiscuindo-a na ordem social. Uma postura contrária à opinião comum pode ser entendida: 1) como "risível”, já que ironicamente Bayle diz nas Adições "que somente pode se tornar ridículo em todos os tempos e, sobretudo, em um século como o nosso, quando se opõe à notoriedade pública." ${ }^{\prime 1}$; 2) mas também ir contra a mentalidade da maioria pode ser um grande perigo, uma vez que a multidão pode se voltar contra aquele (s) que é (são) de opinião díspar, já que o filósofo "se vê reduzido à necessidade de crer no que todo mundo acreditava, com medo de

\footnotetext{
${ }^{6}$ Bayle cita entre tais autores o físico Tycho-Brahé e o historiador Jean Bodin, por exemplo. (parágrafos $\S 13$ e $\$ 25$ respectivamente dos $P D$ ) Uma lista mais pormenorizada de tais autores criticados por Bayle ver, JORINK, E. "Comets in context. Some Thoughts on Bayle's Pensées diverses". In: BOTS, Hans/VAN BUNGE, Wiep. Pierre Bayle (1647-1706), Le philosophe de Rotterdam: philosophy, religion and reception. Brill: Leiden/ Boston, 2008, pp. 51-68. Ver também as notas de rodapé da edição dos PD de A. Prat, Paris: Librairie E. Droz, 1939,2 vols.

7 "Após o que eu venho a dizer, seria supérfluo refutar em particular o preconceito da tradição; porque é visível que, se a prevenção onde se está de tempos imemoriais sobre o capítulo dos cometas pode ter algum fundamento legítimo, ele consiste inteiramente no testemunho que as histórias e os outros livros renderam sobre isto em todos os séculos; de sorte que esse testemunho não deve ser de nenhuma consideração, como eu justifiquei e como ele aparecerá mais ainda pelo que me resta a dizer, não é preciso levar em conta a multidão dos sufrágios que são fundados sobre isso." [“Après ce que je viens de dire, il serait superflu de réfuter en particulier le préjugé de la tradition; car il est visible que, si la prévention où l'on est de temps immémoriel sur le chapitre des comètes peut avoir quelque fondement légitime, il consiste tout entier dans le témoignage que les histoires et les autres livres ont rendu sur cela dans tous les siècles; de sorte que si ce témoignage ne doit être d'aucune considération, comme je l'ai justifié et comme il paraitra encore davantage par ce qui me reste à dire, il ne faut aucun compte de la multitude des suffrages qui sont fondés là-dessus."](BAYLE, 2007, §7, p. 72; OD III[PD], p.12a).

${ }^{8}$ DELPLA, I; DE ROBERT, P. La raison corrosive: études sur la pensée critique de Pierre Bayle. Paris: Honoré Champion, 2003, p. 155-56.

${ }^{9} P D, 2007$, p. 72; OD III[PD], p. 12a. No original: "Que ne pouvons-nous voir ce qui se passe dans l'esprit des hommes lorsqu'ils choisissent une opinion!"

${ }^{10}$ DELPLA, I; DE ROBERT, P. La raison corrosive: études sur la pensée critique de Pierre Bayle. Paris: Honoré Champion, 2003, p. 157.

${ }^{11} O D$ III $[A P D]$, p. $173 b$. No original: "Qu'on ne peut que se rendre ridicule en toute temps, \& surtout dans un siècle comme le nôtre, quand on s'oppose à la notorieté publique."
}

\begin{tabular}{|c|c|l|l|c|c|}
\hline intuitio & $\begin{array}{c}\text { ISSN } \\
1983-4012\end{array}$ & Porto Alegre & Vol.7 $-\mathrm{N}^{\circ} .2$ & $\begin{array}{c}\text { Novembro } \\
2014\end{array}$ & p. 172-183 \\
\hline
\end{tabular}


passar por um faccioso que quer só saber mais do que todos os outros e contradizer a venerável Antiguidade"12 ; 3) e Bayle, mesmo inquieto com questões que, a todo momento, lhe eram feitas pelos mais crédulos, entrevê a dificuldade em esclarecer as pessoas. Quando uma determinada opinião se torna lugar comum e se torna parte integrante da sociedade, se instaura o pleno desinteresse da maioria das pessoas em saber a verdade das coisas, e dessa forma se ganha "pouca coisa pelos raciocínios filosóficos."13

Contudo, se tal dificuldade se dá entre aqueles que, por sua propensão natural a crer em tudo que lhes é dito sem razões suficientes e esclarecedoras, Bayle empreende a sua crítica ao "sofisma da autoridade" 14 e a tarefa para isto cabe à filosofia. O pensador de Carla associa a filosofia à concepção de exame $e^{15}$, isto é, cabe ao filósofo examinar ou passar em revista a origem, a lógica, a intenção e os efeitos de uma opinião corrente. Nos Pensées diverses, ele diz:

${ }^{12} P D, 2007$,p. 73; OD III[PD], p. 12a. No original: "De sorte que le nombre de sectateurs crédules et paresseux s'augmentant de jour en jour a été un nouvel engagement aux autres hommes de se délivrer de la peine d'examiner une opinion qu'ils voyaient si genérale et qu'ils se persuadaient bonnement n'être devenue telle que par la solidité des raisons desquelles on s'était servi d'abord pour l'établir; et enfin on s'est vu réduit à la necesité de croire que tout le monde croyait, de peur de passer pour un factieux quo veut lui seul en savoir plus que tous les autres et contredire la venérable Antiquité." Valendo-se aqui neste caso da prudência, Bayle diz nos $P D$ : "E como eu tomo toda sorte de precauções para não ser reconhecido o autor desta Carta sobre os cometas, que foi impressa na Holanda poucos meses após a minha chegada, eu não mudei nada na linguagem a qual falei. Creio que nada seria mais próprio que uma tal linguagem a fazer julgar que a Carta aos cometas não era de modo algum o escrito de um homem saído da França pela Religião"["Et comme je pris toute sorte de précautions pour ne pas être reconnu l'auteur de cette Lettre sur les comètes, qui fut imprimée en Hollande peu de mois après mon arrivée, je ne changeai rien dans le langage dont j'ai parlé. Je crus que rien serait plus propre qu'un tel langage à faire juger que la Lettre sur les comètes n'était point l'écrit d'un homme sorti de France pour la Religion."'] (2007, “Avertissement au lecteur", p. 60-61; OD III[PD], p. 7a). Na CPD, Bayle diz a respeito ao que podem se expor escritores que vão na contramão da opinião comum: "Eu digo então, Senhor, que todo escritor que ataca as opiniões geralmente aprovadas se expõe a indignar os Leitores. Ele torna-se suspeito de uma vaidade temerária e de um espírito de singularidade que desagrada as pessoas modestas e mais ainda os corações orgulhosos e invejosos. É porque ele deve recorrer a tudo_ para mostrar que, se ele se afasta do caminho trilhado, é por grandes razões. Eis de um lado o melhor meio de subtrair à inveja seus mais belos pretextos, e de outro a melhor satisfação que se possa dar às pessoas honestas, que as aparências de singularidade possam ter colocado mau humor."["Je dis donc, Monsieur, que tout écrivain qui attaque les opinions généralement aprouvées s'expose à indigner ses Lecteurs. Il se rend suspect d'une vanité teméraire, \& d'un esprit de singularité qui deplaît aux gens modestes, \& plus encore aux coeurs orgueilleux \& envieux. C'est pourquoi il doit mettre tout en oeuvre pour faire voir que s'il s'écarte du chemin battu, ce n'est que pour de très-grands raisons. Voilà d'un coté le meilleur moyen d'ôter à l'envie ses plus beaux prétextes, \& de l'autre la meilleure satisfaction que l'on puisse faire aux honnêtes gens, que les apparences de singularité peuvent mis de mauvaise humeur.’](OD III[CPD], p. $240 a)$.

${ }^{13} P D$, 2007, p. 59; $O D$ III $[P D], 7 a$. No original: "Je rassurais autant qu'il m'était possible ceux qui s'inquiétaient de ce prétendu mauvais présage; mais je ne gagnais que peu de chose par les raisonnements philosophiques; on me répondait toujours que Dieu montre ces grandes phenomènes afin de donner le temps aux pécheurs de prévenir par leur pénitence les maux qui leur perndent sur la tête."

${ }^{14} P D, 2007$, p. 74; OD III $[P D], 12 b$. No original: "Sophisme d'autorité."

${ }^{15}$ Conceito chave principalmente no Commentaire philosophique sur ces paroles de Jésus-Christ "Contrains-les d'entrer" -1686, doravante $C P h$ - sendo que o exame por meio da razão torna-se um "critério", "medida" (Cf. 1992, I, i, p. 89) "regra original" (Id. Ibid.) ou "regra matriz, primitiva e universal de julgar e discernir o verdadeiro do falso, o bom e o mau." (Id. Ibid., p. 95). Cf. também sobre o mesmo assunto o Supplément du Commentaire philosophique - doravante SCPh - cap. XVII, p. 136-147. Ver também OD III[CPD], p. 224b. Para Gianluca Mori, é na noção de exame que reside a originalidade do pensamento de Bayle: "A originalidade de Bayle reside precisamente nesta opinião de fundo: ao invés de ligar o ateísmo a tal ou tal doutrina metafísica - a alma do mundo, o monismo espinosista, o atomismo epicurista - ele o faz, antes de tudo, uma opinião epistemológica (e moral), identificando-o, de fato, com a própria filosofia, com a noção de examen, como que

\begin{tabular}{|c|c|c|c|c|c|}
\hline intuitio & $\begin{array}{c}\text { ISSN } \\
1983-4012\end{array}$ & Porto Alegre & Vol.7 - No.2 & $\begin{array}{c}\text { Novembro } \\
2014\end{array}$ & p. 172-183 \\
\hline
\end{tabular}


Eu digo mais uma vez, é uma pura ilusão pretender que um sentimento que passa de século em século e de geração em geração não possa ser inteiramente falso. Por pouco que se examinem as causas que estabelecem certas opiniões no mundo e as que as perpetuam de pai para filho, ver-se-á que não há nada de menos razoável que esta pretensão. Confessar-me-ão sem dúvida que é fácil persuadir o povo de certas opiniões falsas que se conciliam com os preconceitos da infância ou com as paixões do coração, como são todas as pretensas regras dos presságios. Eu não pergunto ainda, por isso basta para tornar essas opiniões eternas; porque, à exceção de poucos espíritos filósofos, ninguém pensa em examinar se o que se ouviu por toda parte é verdadeiro. $^{16}$

A ilusão oriunda de uma crença irrefletida em uma falsa opinião, segundo Bayle, foi reforçada por dois fatores: o preconceito adquirido e reforçado desde a infância e passado de geração a geração, e as paixões do coração sendo eminentemente da ordem do sentimento, e não da razão ${ }^{17}$. Esta, em contrapartida, realizando um exame minucioso justamente acerca da legitimidade de opiniões disseminadas e solidificadas no decorrer dos tempos, poderá mostrar a falsidade desde sempre

nos resta de idéias claras e distintas, que a fé nos impõe renegar em nome de uma divinação divina superior." (1999, p. 270-271)

${ }^{16} P D, 2007$, p. 235; OD III $[P D]$, p. 68a, grifos meus. No original: "Je dis encore un coup, c'est une illusion toute pure que de prétendre qu'un sentiment qui passe de siècle en siècle et de génération en génération ne peut être entièrement faux. Pour peu qu'on examine les causes qui établissent certaines opinions dans le monde et celles qui les perpétuent de père en fils, on verra qu'il n'y a rien de moins raisonnable que cette prétention. On m'avouera sans doute qu'il est facile de persuader au peuple certaines opinions fausses qui s'accordent avec les préjugés de l'enfance ou avec les passions du coeur, comme sont toutes les prétendues règles des présages. Je n'en demande pas davantage, car cela suffit pour rendre ces opinions éternelles; parce qu'à la reserve de quelques esprits philosophes, personne ne s'avise d'examiner si ce que l'on entend dire partout ets véritable.”O título do $\S$ 8 dos PD é sugestivo: Porque não falam de modo algum da autoridade dos filósofos. E eis a razão, segundo Bayle: "É porque estou persuadido de que, se o testemunho dos filósofos fez alguma impressão sobre vosso espírito, é somente porque ela torna a tradição mais geral e não por causa das razões sobre as quais ela se apoiou. Vós sedes muito hábil para ser ingênuo com qualquer filósofo que seja, visto que eu vos ataco somente pela via do raciocínio; e é preciso vos conceder esta justiça que, nas coisas que vos credes ser da alçada da razão, seguistes somente a razão pura. Assim, não são os filósofos enquanto filósofos que contribuíram a vós se tornardes povo esta ocasião, visto que é certo que todos os seus raciocínios a favor das malignas influências causam piedade. Querei-vos então que eu diga, na qualidade de antigo amigo, de onde vem que vos destes em uma opinião comum sem consultar o oráculo da razão? É que vos credes que há alguma coisa de divino em tudo isto, como disseram de certas doenças após o famoso Hipócrates; é que vos imagineis que o consentimento geral de tantas nações no decorrer de todos os séculos só pode vir de uma inspiração, vox populi, vox Dei."["CC'est parce que je suis persuadé que, si le témoignage des philosophes a fait quelque impression sur votre esprit, c'est seulement à cause qu'il rend la tradition plus générale et non pas à cause des raisons sur lesquelles il est appuyé. Vous êtes trop habile pour être la dupe de quelque philosophe que ce soit, pourvu qu'il ne vous attaque que par la voie du raisonnement; et il faut vous rendre cette justice que, dans les choses que vous croyez être du ressort de la raison, vous ne suivez que la raison toute pure. Ainsi, ce ne sont pas les philosophes en tant que philosophes qui ont contribué à vous rendre peuple em cette occasion, puisqu'il est certain que tous leurs raisonnements en faveur des malignes influences font pitié. Voulez-vous donc que je vous dise, en qualité d'ancien ami, d'où vient que vous donnez dans une opinion commune sans consulter l'oracle de la raison? C'est que vous croyez qu'il y a quelque chose de divin dans tout ceci, comme on l'a dit de certaines maladies après le fameux Hippocrate; c'est que vous vous imaginez que le consentement général de tant de nations dans la suite de tous les siècles ne peut venir que d'une espèce d'inspiration, vox populi, vox Dei.’] (2007, pp. 73-74; OD III[PD], p. 12b).

${ }^{17}$ Raciocínio similar no $S C P h$ : "Que como o que os Juízes não podem sempre discernir o inocente do culpado, e que com as melhores intenções de fazer justiça, absolvem algumas vezes este e punem aquele, faz bem ver que eles têm o espírito limitado e sujeito a grandes ilusões, consequiências inevitáveis da humanidade, mas não que eles odeiem a justiça e que, por uma vontade infectada de corrupção, querem ser injustos." ["Que comme ce que les Juges ne peuvent pas toujours discerner l'innocent d'avec le coupable, \& qu'avec les meilleures intentions de faire justice, ils absolvent quelquefois celui-ci, \& punissent celui-là fait bien voir qu'ils ont l'esprit borné, \& sujet à de grandes illusions, suites inévitables de l'humanité, mais non pas qu'ils haïssent la justice, \& que par une volonté infectée de corruption ils veulent être injustes.”] (XIX, p. 161; OD II[SCPh], p. 517b).

\begin{tabular}{|c|c|c|c|c|c|}
\hline intuitio & $\begin{array}{c}\text { ISSN } \\
1983-4012\end{array}$ & Porto Alegre & Vol.7 $-\mathrm{N}^{\mathrm{o}} .2$ & $\begin{array}{c}\text { Novembro } \\
2014\end{array}$ & p. 172-183 \\
\hline
\end{tabular}


subjacente em proposições não apoiadas em demonstrações e provas factuais, mas somente em arbitrariedades e conjecturas ${ }^{18}$. Com ironia, Bayle menciona que para "pequenos" autores como ele ${ }^{19}$, seria da maior inconveniência tratar determinadas questões de modo rápido e conciso, sendo tal postura somente aceitável "em um homem de uma grande autoridade entre os doutos." ${ }^{20}$ Em meio a um debate, é mister estar sempre preparado, expondo ampla e cuidadosamente todas as razões, e sustentá-las firmemente diante dos adversários, não dando a menor margem de possibilidade a objeções ou refutações. Procedendo de tal maneira, tais filósofos fazem ver que "os interesses da verdade, bem ou mal conhecida, são o meio que os tira do grande caminho e é um motivo de consolação ou de uma grande edificação para as pessoas razoáveis que de outro modo poderiam escandalizar-se." ${ }^{21}$ Nesse sentido, o filósofo de Carla exige um critério mais rigoroso quando se trata do esclarecimento de alguma opinião, já que

[...] é uma péssima prova da verdade de uma coisa dizer que uma infinidade de pessoas a afirmaram. Temeis que isso seja de uma perigosa consequência em relação a doutrinas que nos devem ser infinitamente preciosas. Respondo-vos, Senhor, que nada deveis temer por aí. As grandes e importantes verdades possuem caracteres interiores que as sustentam: são por estes signos que devemos discernir, e não por caracteres exteriores que só podem ser equívocos, se eles convêm tanto à falsidade como à verdade. ${ }^{22}$

Em outros termos, Bayle associa a opinião à pura probabilidade e depois de bem examinada, $o$ percentual de chance de estar correta diminui drasticamente, pois, na questão da simetria entre ateísmo e moralidade, por exemplo, os que "creem que o Ateísmo é o estado mais execrável que o homem possa se encontrar, ultrapassam o número dos que afirmam o contrário." ${ }^{23}$ São esses raros "espíritos

${ }^{18}$ E é a exigência de Bayle em toda e qualquer contenda. Na CPD ele assevera, por exemplo, a respeito do paradoxo do ateísmo virtuoso: "Vindo ao fundo do processo, eu vos peço para considerar que o que chamastes de meu paradoxo e um paradoxo escandaloso é uma proposição que eu não expus sem sustentá-la por muitas provas, que pareceram convincentes a muitos Leitores e que ninguém ainda pensou em atacá-la diretamente. Vós bem as examinastes? Tendes algo de sólido para aí responder? Sem isto, vosso escândalo só pode ser malfundado." ["Venant au fond de l'affaire, je vous prie de considérer que ce que vous apellez mon paradoxe, \& un paradoxe scandaleux, est une preuve que je n'ai avancée sans la soutenir par beaucoup de preuves, qui ont paru convaincantes à plusieurs Lecteurs, \& que personne ne s'est encore avisé d'attaquer directement. Les avez-vous bien examinées? Avez-vous quelque chose de solide à y répondre? Sans cela votre scandale ne peut être que mal fondé.”](OD III[CPD], p. $296 a$, grifos meus.)

19"Mas para pequenos autores como eu, nada saberia ser mais inconveniente que o estilo lacônico em semelhantes encontros." ["Mais pour de petits Auteurs comme moi, rien ne sauroit être messéant, que le style laconique dans de semblables rencontres.”] (OD III[CPD], p. 240b).

${ }^{20} O D$ III $[C P D]$, p. $240 b$. No original: "[...] dans un homme d'une grande autorité parmi les doctes."

${ }^{21} O D$ III $[C P D]$, p. $240 b$. No original: "Ils font voir par-là que les intérêts de la vérité, bien ou mal connue, sont le ressort qui les tire du grand chemin, \& est un sujet de consolation, ou d'une grande édification pour les personnes raisonnables que autrement eussent pû se scandaliser."

${ }^{22} O D$ III $[C P D]$, p. 193ab. No original: “[...] c'est une très-mauvaise preuve de la verité d'une chose que de dire qu'une infinité de gens l'ont affirmée. Vous craignez que cela ne soit d'une dangereuse conséquence par rapport à des doctrines, qui nous doivent être infiniment précieuses. Je vous réponds, Monsieur, que vous ne devez rien craindre de ce côté-là. Les grandes \& les importantes verités ont des caractères interieurs qui les soûtiennent: c'est à ces signes que nous les devons discerner, \& non par des caractères extérieurs qui ne peuvent être qu'équivoques, s'ils conviennent tantôt à la fausseté, tantôt à la vérité.".

${ }^{23} O D$ III[CPD], p. 304b. No original: "Vous ne manquerez pas de me répliquer que le nombre des Auteurs, qui croient que l'Athéisme est l'état le plus execrable où l'homme se puisse trouver, surpasse le nombre de ceux qui

\begin{tabular}{|c|c|c|c|c|c|}
\hline intuitio & $\begin{array}{c}\text { ISSN } \\
1983-4012\end{array}$ & Porto Alegre & Vol.7- No.2 & $\begin{array}{c}\text { Novembro } \\
2014\end{array}$ & p. 172-183 \\
\hline
\end{tabular}


filósofos" que vão tratar de fazer uma investigação acurada acerca da verdadeira causa da emissão, propagação e consequentemente a consolidação de uma opinião. Bayle insiste neste ponto nevrálgico: a ilusão de uma tradição fortalecida em pensar que está isenta de falsidade. Segundo o filósofo de Carla, a imposição do nome e título de sábio de nada serve para fazer com que se aceite que a verdade está na tradição, mas, ao contrário, só alimenta ainda mais a suspeita de que aquela precisa ser explorada mais a fundo, ser desmistificada. A opinião de um homem só terá mais validade do que outra de acordo com seu grau de certeza, uma vez que se instruiu realmente a respeito do que está sendo colocado em questão. Bayle diz:

Por aí, parece que os sábios estão algumas vezes, em uma tão perigosa suspeita quanto o povo, e que uma tradição fortificada por seu testemunho não é por isso isenta de falsidade. Não é preciso então que o nome e o título de sábio nos sejam impostos. Que sabemos nós se esse grande doutor que expõe alguma doutrina anunciou mais de modo a se convencer que um ignorante que acreditou nele sem examinar? Se o doutor o fez igualmente, sua voz não tem mais autoridade que a de outro, visto que é certo que o testemunho de um homem só deve ter força à proporção do grau de certeza que se adquiriu instruindo-se plenamente de fato. ${ }^{24^{3}}$

Equiparando o peso das duas opiniões, ou seja, o do povo e a dos sábios, ambas, sem um exame minucioso prévio do que sustentam, não têm valor algum. Contudo, há justamente uma espécie de "transferência" do saber para os sábios. Entretanto, a despeito dos títulos, daí não se obtém convencimento algum do que é proferido sem conhecimento algum do que está sendo debatido. Bayle fala em graus de certeza, ou seja: mesmo não estando certo de se alcançar uma verdade absoluta, é mais provável ter uma opinião mais vigorosa e fundamentada instruindo-se mais a fundo, ou seja,

affirment le contraire." No mesmo parágrafo, Bayle critica os que, já em uma primeira impressão, acreditam em algo, ou seja, ele levanta o problema da evidência de um julgamento acerca de um determinado objeto: "Uma outra coisa pode servir de obstáculo a uma justa escolha. Não se imprime muito fortemente esta consideração que há em cada partido um forte e um fraco, e que é preciso somente decidir após comparar exatamente o forte de um ao forte de outro, e o fraco de um ao fraco de outro. Porque se somente se compara o forte ao fraco como se faz ordinariamente quando uma paixão secreta inspira preconceitos, expõe-se a mil ilusões. Não é preciso mais se limitar a seus primeiros movimentos, há objetos que nos arrebatam ou que nos assustam à primeira vista. Julgando sobre esta primeira impressão, podereis aí estar enganado. Vale mais então deixá-la passar e esperar o que dirá nosso espírito após ter feito o giro do objeto e aí ter bem considerado pela parte anterior e por trás. Não está fora de propósito colocá-lo sob um outro ponto de vista."'“"Une autre chose peut servir d'obstacle à un juste choix. On ne s'imprime pas assez fortement cette considération, qu'il y a dans chaque parti un fort \& un faible, \& et le faible de l'un au faible de l'autre; car si l'on compare que le fort au faible, comme l'on fait ordinairement lorsqu'une passion secrète inspire des préjugés, on s'expose à cent illusions. Il ne faut point non plus s'arrêter à ses premiers mouvements; il y a des objets qui nous ravissent, ou qui nous effraient à la première vue. Jugez-en sur cette première impression, vous y pourrez être fort trompé. Il vaut donc mieux la laisser passer, $\&$ attendre ce que dira notre esprit après avoir fait le tour de l'objet, \& avoir bien consideré par devant \& par derrière. Il n'est pas hors de propos de le mettre sous un autre point de vue"]. (Id. Ibid., p. 305b). Ver também o parágrafo LXXX da mesma obra intitulado Porque se pode crer que aqueles que preferiram o Paganismo ao Ateísmo, não examinaram bem a questão. (grifo meu)

${ }^{24}$ PD. 2007, p. 137; $O D$ III $[P D]$, p. 35a. No original: "Il paraît de là que les savants sont quelques fois une aussi méchante caution que le peuple, et qu'une tradition fortifíée le leur témoignage n'est pas pour cela exempte de fausseté. Il ne faut donc pas que le nom de le titre de savant nous impose. Que savons-nous si ce grand docteur qui avance quelque doctrine a apporté plus de façon à s'en convaincre qu'un ignorant qui l'a crue sans l'examiner? Si le docteur en a fait autant, sa voix n'a pas plus d'autorité que celle de l'autre, puisqu'il est certain que le témoignage d'un homme ne doit avoir de force qu'à proportion du degré de certitude qu'il s'est acquis en s'instruisant pleinement du fait".

\begin{tabular}{|c|c|c|c|c|c|}
\hline intuitio & $\begin{array}{c}\text { ISSN } \\
1983-4012\end{array}$ & Porto Alegre & Vol.7 $-\mathrm{N}^{\circ} .2$ & $\begin{array}{c}\text { Novembro } \\
2014\end{array}$ & p. 172-183 \\
\hline
\end{tabular}


situando-se nos antípodas de uma pseudosapiência mais considerada pelo que aparenta saber do que realmente por ter conhecimento de causa. Nas palavras de Delpla, "esta extensão da autoridade intelectual em prol do personagem social do sábio decorre da credulidade, da ausência de espírito crítico e de uma preguiça que dispensam de verificar o alcance de um saber."${ }^{, 25}$

Segundo Bayle, um sentimento só pode se tornar provável uma vez que se apresentou como verdade àqueles que sequer empregaram um esforço mínimo em empreender um exame acurado do que sempre lhes é mostrado, até mesmo imposto, seja por meio de discursos, livros e todo veículo de informação possível e digno de suspeita. Não tendo um conhecimento mais aprofundado das coisas, a multidão não ultrapassará os limites do que lhe parece a verdade:

Eu vos disse antes e ainda repito: um sentimento só pode se tornar provável pela multidão daqueles que o seguem igualmente ao que pareceu verdadeiro a muitos, independentemente de toda prevenção e pela força única de um exame judicioso, acompanhado da exatidão e de uma grande inteligência das coisas; e como bem foi dito que um testemunho que viu é mais crível que dez que falam por ouvir-dizer, pode-se também assegurar que um homem hábil que só debita o que ele meditou extremamente e que encontrou à prova de todas as suas dúvidas dá mais peso a seu sentimento que cem mil espíritos vulgares que seguem como carneiros e depositam tudo na boa fé de outrem. ${ }^{26}$

A insistência do filósofo é para reforçar justamente seu argumento de que exame, meditação e um vasto conhecimento das coisas são elementos imprescindíveis para, pelo menos, se outorgar o direito de discutir sobre um determinado tema proposto. Além de todos esses fatores, Bayle valoriza mais um testemunho ocular, ou seja, que viu o que se passou, contrariamente a inúmeros que apoiaram seus julgamentos temerários em outras opiniões já proferidas também arbitrariamente, e que fizeram da pretensa boa fé dos outros a depositária de sua cegueira. A denúncia de um certo espírito de rebanho característico em um contexto que o espírito crítico de sondagem das opiniões se situa à margem serve para constatar a inércia de um círculo social que sempre entende que a quantidade e não

${ }^{25}$ DELPLA, I; DE ROBERT, P. La raison corrosive: études sur la pensée critique de Pierre Bayle. Paris: Honoré Champion, 2003, p.155.

${ }^{26} P D, 2007$, p. 137; $O D$ III $[P D]$, p.35b. No original: “Je vous l'ai déjà dit et je le répète encore: un sentiment ne peut devenir probable par la multitude de ceux qui le suivent qu'autant qu'il a paru vrai à plusieurs indépendamment de toute prévention et par la seule force d'un examen judicieux, accompagné d'exactitude et d'une grande intelligence des choses; et comme on a fort bien dit qu'un témoin qui a vu est plus croyable que dix qui parlent par ouï-dire, on peut aussi assurer qu'un habile homme qui ne débite que ce qu'il a extrêmement médité et qu'il a trouvé à l'épreuve de tous ses doutes donne plus de poids à son sentiment que cent mille esprits vulgaires qui se suivent comme des moutons et se reposent de tout sur la bonne foi d'autrui."

\begin{tabular}{|c|c|c|c|c|c|}
\hline intuitio & $\begin{array}{c}\text { ISSN } \\
1983-4012\end{array}$ & Porto Alegre & Vol.7 $-\mathrm{N}^{\circ} .2$ & $\begin{array}{c}\text { Novembro } \\
2014\end{array}$ & p. 172-183 \\
\hline
\end{tabular}


a veracidade das opiniões obtém estatuto de verdade ${ }^{27}$. Nesse contexto, é mister "se servir do método de pesar as vozes e não contá-las". ${ }^{28}$

Bayle é pontual: em filosofia, é preciso afastar o julgamento do vulgo e analisar os fatos e fenômenos naturais tanto pela experiência como pela razão. Fazer da oscilante multiplicidade opinativa um método para julgar uma contenda, é querer incorrer em uma série de equívocos os quais podem comprometer sua legitimidade:

[...] sempre retorno a isso: que não é preciso contar as vozes, que é preciso pesá-las, e que o método de decidir uma controvérsia pela pluralidade das vozes, está sujeito a tantas injustiças, que só há a impossibilidade de fazer de outro modo que o torne legítimo em certos casos. ${ }^{29}$

A impossibilidade consiste na incerteza de saber qual sufrágio vale mais que outro, uma vez que não se tem nem a competência nem as "luzes necessárias" para estabelecer a validade de cada parecer, precisando que se tolere que uma opinião valha tanto quanto outra em determinadas situações. ${ }^{30}$ Contudo, Bayle inverte os termos: visto que os embates filosóficos não são dessa estirpe, é

${ }^{27}$ Quanto à insustentabilidade do seu paradoxo do ateu virtuoso, Bayle diz na $C P D$ : “Crede-vos, Senhor, que com a pluralidade de tais sufrágios se possa tornar superior a probabilidade da tese oposta ao meu paradoxo? Penseis aí bem, encontrareis que esta pluralidade vem de uma fonte que enfraquece extremamente a decisão."' "Croïez-vous, Monsieur, qu'avec la pluralité de tels sufrages on puisse rendre supérieure la probabilité de la these oposée à mon paradoxe? Songez-y bien, vous trouverez que cette pluralité vient d'une source que afoiblit extrêmement la décision."] ( $O D$ III, p. 306b).

${ }^{28} O D$ III $[C P D]$, p. 194b-195a. No original: "[...]se servir de la méthode de peser les voix, \& non pas de les compter." Entretanto, para não aceitarmos acriticamente essa varredura das falsas opiniões exigida por Bayle, vale lembrar que o filósofo abre exceções para tal postura como, por exemplo, em assuntos de jurisprudência e política, pois entende que uma assembleia é necessária para decisões governamentais e uma única opinião contrária colocaria em descrédito toda e qualquer decisão, causando mal-estar. A prudência, neste caso, é necessária em prol da conservação do corpo político. Bayle afirma na CPD: "Se a jurisprudência e a política têm deixado a decisão dos processos é porque não foi possível se servir do método de pesar as vozes e não contá-las. $\mathrm{O}$ método que foi preciso empregar com toda a necessidade está sujeito a grandes inconvenientes. A justiça, a razão e a prudência estão do lado do pequeno número em cem ocasiões, tal como é o único de seu parecer, opina mais sabiamente que todo o resto da companhia. As mais sábias cabeças de uma assembleia têm frequentemente o desprazer de ver que a cabala de jovens dominados e pouco esclarecidos obtém na pluralidade das vozes uma decisão iníqua, temerária e perniciosa. Mas é preciso passar por isso, porque se fosse estabelecida a necessidade do concurso de todos os sufrágios e se, como nas Dietas da Polônia, a oposição de um único deputado pudesse tornar nulas todas as deliberações, lançar-se-ia em um abismo muito mais funesto." ["Je vous dirois en deuxième lieu que si la Jurisprudence, \& la politique ont laissé la décision des affaires au jugement du plus grand nombre, c'est à cause qu'il n'a pas été possible de se servir de la méthode de peser les voix, \& non pas de les compter. La méthode qu'il a fallu emploïer de toute necessité est sujette à de grands inconvénients. La justice, la raison \& la prudence sont du côté du petit nombre en cent occasions, \& tel qui est seul de son avis opine plus sagement que tout le reste de la compagnie. Les plus sages têtes d'une assemblée ont très-souvent le déplaisir de voir que la cabale des jeunes gens emportez, \& peu éclairez obtient à la pluralité des suffrages une décision inique, téméraire \& pernicieuse. Mais il faut passer par-là, car si l'on établissoit la nécessité du concours de tous les suffrages, \& si comme dans les Dietes de Pologne, l'oposition d'un seul Député pouvoit rendre nulles toutes les déliberations, on se jetteroit dans une abîme beaucoup plus funeste.”] (Id. Ibid.)

${ }^{29} P D, 2007$, p. 138; $O D$ III $[P D]$, p. 35b. No original: "Je n'approuve pas ces manières, mais j'en reviens toujours là, qu'il ne faut pas compter les voix, qu'il faut les péser, et que la méthode de décider une controverse à la pluralité des voix est sujette à tant d'injustices qu'il n'y a que l'impossibilité de faire autrement qui la rende légitime en certains cas."

30 “[...] não há ninguém no mundo que possa determinar exatamente quanto um sufrágio vale mais que outro, não possuindo nem a jurisdição nem as luzes necessárias para reduzir as opiniões dos membros de uma companhia, cada uma a seu justo preço, de modo que é mister necessariamente tolerar que um valha tanto quanto o outro em certos casos." ["C'est qu'il n'y a personne sur la terre qui puisse déterminer au juste combien un suffrage vaut que

\begin{tabular}{|c|c|l|l|c|c|}
\hline intuitio & $\begin{array}{c}\text { ISSN } \\
1983-4012\end{array}$ & Porto Alegre & Vol.7- $\mathrm{N}^{\mathrm{o}} .2$ & $\begin{array}{c}\text { Novembro } \\
2014\end{array}$ & p. 172-183 \\
\hline
\end{tabular}


preciso reduzir a nada os pontos de vista dos crédulos e supersticiosos, levando em conta o pequeno número de filósofos. Nesse sentido, vai de encontro à velha máxima "a voz do povo é a voz de Deus" a qual é a fonte dos pensamentos mais absurdos:

Mas, visto que as Controvérsias de Filosofia não são desta espécie, nos é deveras permitido computar como nada os sufrágios ${ }^{31}$ de uma infinidade de pessoas crédulas e supersticiosas e antes, aquiescer às razões de um pequeno número de Filósofos. Assim, Mr., sem ter consideração ao vosso Vox populi, vox Dei, que autorizaria os pensamentos mais ridículos, se aí o seguissem, eu seria muito da opinião que se examinasse primeiramente se é verdadeiro que os anos que acompanharam de perto os cometas foram sempre notáveis pelos fatos mais trágicos do que aqueles que se vê acontecer em outros tempos. ${ }^{32}$

O descrédito do vulgo é claro, e Bayle não mede esforços em fulminar a "legitimidade" dos sufrágios. Em oposição ao pequeno número de pregadores que foram os arautos da superstição, Bayle evoca o restrito círculo dos filósofos que justamente tem a incumbência de investigar as apreciações dos crédulos. E ainda vai mais longe, mostrando que opiniões em nada condizem com as ações. Levando em conta a capacidade humana das mais gritantes aberrações no que concerne a outrem, em relação a si próprios estabelecem inúmeras exceções. Bayle afirma: não são opiniões especulativas que são o móbil das ações, e sim as paixões que se encontram no coração do homem ${ }^{33}$. Muito raramente os homens agem de acordo com seus princípios. Mesmo hábeis em matérias de ordem especulativa,

l'autre, qui ait ni la juridiction ni les lumières nécessaires pour réduire les opinions des membres d'une compagnie chacune à son juste prix, de sorte qu'il faut nécessairement tolérer que l'une vaille autant l'autre dans certains cas."] 2007 , p. 138, OD III[PD],p.35b-36a).

${ }^{31} \mathrm{O}$ significado do termo sufrágio atualmente tem o mesmo sentido jurídico e eleitoral como era utilizado no século XVII. Ver DUBOIS, Jean; LAGANE, René; LEROND, Alain. Dictionnaire du français classique: XVIIe siècle. Paris: Larousse, 1988, p.518 (Références Larousse).

${ }^{32} P D, 2007$, p. 138; OD III[PD], p.36a. No original: "Mais puisque les controverses de philosophie ne sont pas de cette espèce, il nous est fort permis de compter pour rien les suffrages d'une infinité de gens crédules et superstitieux, et d'acquiescer plutôt aux raisons d'un petit nombre de philosophes. Ainsi, Monsieur, sans avoir égard à votre vox populi, vox Dei, aphorisme qui autoriserait les pensées plus ridicules si on le suivait, je serait fort d'avis qu'on examinât premièrement s'il est vrai que les années qui ont suivi de près les comètes aient toujours été remarquables par des événements plus tragiques que ceux qu'on voit arriver dans d'autres temps." Bayle mostra o filósofo como o agente esclarecedor dos verdadeiros fundamentos de uma opinião. Opõe a clareza da razão às obscuras proposições pela tradição. Hume aqui é fiel ao filósofo francês. A razão, desde que seja clara, é o antídoto contra a corrupção das opiniões humanas: "A razão, quando clara, previne tais corrupções; quando abstrusa, mantém os princípios inteiramente afastados do conhecimento das pessoas comuns, que só são propensas a corromper um princípio ou opinião.” HUME, História da religião natural, seção 1, p. 28. Vale atentar também para a importante distinção entre um combate entre ideias, estando sob os auspícios da razão, e o propriamente físico e moral, fomentado desmedidamente pelos religiosos. Tal distinção encontra-se na Republique des Lettres de Bayle. Segundo J.-M. Gros, “com efeito, a diferença é dupla: é que, antes de tudo, no combate intelectual, existem critérios - argumentos conclusivos, experiências cruciais, o testemunho de documentos irrefutáveis,etc. Contrariamente, no conflito religioso, como a fé, por definição, não é de ordem discursiva, a violência não tem limite, carecendo de uma conclusão de ponto de apoio para um acordo comum. $\mathrm{O}$ conflito aí não faz ninguém progredir e degenera em uma guerra tanto cruel e absurda, como sem razão. A segunda diferença decorre da primeira: na guerra religiosa, não podendo convencer por um argumento ou uma experiência irrefutável, dirigem-se à pessoa, seja física ou moralmente." "Pierre Bayle et la Republique des Lettres", In: MCKENNA, Antony \& MOREAU, Pierre-François. Libertinage et philosophie au XVIIe siècle. Saint-Étienne: Presses Universitaires de Saint-Étienne, 2002, p. 138.

33 "O que há então a fazer é nos atermos ao que acontece com mais frequência, a saber, que não são as opiniões gerais do espírito que nos levam a agir, mas as paixões presentes no coração". [ "Ce qu'il y a donc à faire, c'est de s'en tenir à ce qui arrive le plus souvent, savoir que ce ne sont pas les opinions générales de l'esprit qui nous déterminent à agir, mais les passions présentes du coeur. ’](2007, p.297; OD III[PD], p. 89b, itálicos de Bayle).

\begin{tabular}{|c|c|c|c|c|c|}
\hline intuitio & $\begin{array}{c}\text { ISSN } \\
1983-4012\end{array}$ & Porto Alegre & Vol.7 $-\mathrm{N}^{\mathrm{o} .2}$ & $\begin{array}{c}\text { Novembro } \\
2014\end{array}$ & p. 172-183 \\
\hline
\end{tabular}


pecam pela facilidade que têm de assimilarem falsas inferências, do que por suas conclusões das mesmas. Em relação aos costumes, o quadro ainda é mais nefasto: mesmo tendo em suas consciências todas as ideias da equidade natural, concluem sempre a favor de sua extravagante concupiscência. A questão é: se reinam no espírito do homem todos os preceitos religiosos - entre os quais o da equidade - como na prática o que prevalece são as paixões?

De onde vem tudo isso, por favor, ainda que exista entre os homens uma prodigiosa diversidade de opiniões no tocante ao modo de servir a Deus, e viver segundo as leis da decência, contudo, vemos certas paixões reinarem constantemente em todos os Países e em todos os séculos? ${ }^{34}$

Teoricamente, são perfeitos todos os mandamentos religiosos. Uma vez inculcados na consciência, o mais natural seria efetivá-los na prática, independente das maneiras de se venerar uma divindade. Mas, na concretude dos fatos, não é o que acontece, pois as paixões falam mais alto nos homens, tornando-se a regra absoluta de suas respectivas condutas. Tais paixões são traduzidas por toda sorte de malefícios e sacrilégios que um homem pode cometer contra seu próximo, visto que o objetivo principal é agir de acordo com seu temperamento. Bayle reduz a condição humana a tal estado de coisas. Para satisfazer seus desejos, todos os homens são iguais. Copiam-se uns aos outros no que concerne às opiniões, na prática não é diferente:

[...] o Judeu e o Maometano, o Turco e o Mouro, o Cristão e o Infiel, o Indiano e o Tártaro, o habitante de terra firme e o das Ilhas, o Nobre e o Plebeu, todos esses tipos de pessoas que, no resto, só concordam, por assim dizer, na noção geral de homem, são tão parecidos a respeito dessas paixões, que diríamos que eles copiam uns aos outros? ${ }^{35}$

Sem exceção alguma, todos os homens buscam saciar suas paixões por diversos modos, seja pela "avareza, ambição, o desejo de se vingar, a impudicícia." ${ }^{36} \mathrm{O}$ verdadeiro princípio das ações é o temperamento, uma disposição que emerge do fundo da natureza humana, em qualquer lugar que tenha nascido e devido aos seus conhecimentos adquiridos. Segundo Bayle, tudo isso é resultado das diversas superstições reinantes entre os povos, que, querendo apaziguar a ira de seus deuses, inventavam uma série de prodígios, os quais imaginavam serem os promotores dos infortúnios terrenos. Mas por essas vias, também ocorreram os crimes mais atrozes. ${ }^{37}$ Dessa forma, se erige um

\footnotetext{
${ }^{34} P D, 2007$, p. $293 ; O D \operatorname{III}[P D]$, p. $88 a$. No original: "D'où vient, je vous prie, qu'encore qu'il y ait parmi entre les hommes une prodigieuse diversité d'opinions touchant la manière de servir Dieu et de vivre selon les lois de la bienséance, on voit neanmoins certaines passions régner constamment dans les tous les pays et dans tous les siècles?"

${ }^{35} P D, 2007$, p. 293; $O D \mathrm{III}[P D]$, p. 88a. No original: “[...]le juif et le mahométan, le Turc et le Maure, le chrétien et l'Infidèle, l'Indien et le Tartare, l'habitant de la terre ferme et l'habitant des îles, le noble et le roturier, toutes ces sortes de gens qui dans la notion générale d'homme, sont si semblables à l'égard de ces passions que l'on dirait qu'ils se copient les uns les autres?"

${ }^{36} P D, 2007$, p. 293; $O D$ III[PD], p. 88a. No original:“[...]que l'ambition, l'avarice, l'envie, le désir de se venger, l'impudicité et tous les crimes qui peuvent satisfaire ces passions se voient partout?"

37 “É preciso que assim seja, visto que os antigos Pagãos, acabrunhados por uma multiplicidade inacreditável de superstições, perpetuamente ocupados em apaziguar a cólera de seu Deus, apavorados por uma infinidade de prodígios, imaginando que os Deuses eram os Dispensadores da adversidade e da prosperidade segundo a via

\begin{tabular}{|c|c|l|l|c|c|}
\hline intuitio & $\begin{array}{c}\text { ISSN } \\
1983-4012\end{array}$ & Porto Alegre & Vol.7- $\mathrm{N}^{\mathrm{o}} .2$ & $\begin{array}{c}\text { Novembro } \\
2014\end{array}$ & p. 172-183 \\
\hline
\end{tabular}
}


enorme contrassenso: nesse panorama sombrio de crimes religiosos, como é possível que os cristãos, que conhecem com tanta clareza, mediante uma verdade revelada, tantos milagres, ainda precisem abandonar seus vícios com vistas a adquirirem a felicidade eterna?

Se assim não fosse, como seria possível que os Cristãos, que conhecem tão claramente por uma revelação sustentada por tantos milagres, que é preciso renunciar ao vício para ser eternamente feliz, e para não ser eternamente infeliz; que têm tantos excelentes pregadores pagos para aí lhes fazerem as mais vivas e prementes exortações do mundo; que encontram em toda parte tantos Diretores de Consciência zelosos e sábios e tantos livros de devoção; como, afirmo, seria possível, entre tudo isso, que os Cristãos vivessem, como o fazem, nos maiores desregramentos do vício? ${ }^{38}$

Mesmo com tudo que possa impedir atitudes desmedidas na prática tomadas pelos religiosos, Bayle entende que isso é inevitável visto que: 1) o homem, sendo capaz de cometer ações as mais atrozes, "jamais vai impor uma regra a seu respeito que não admita mil exceções"39; e também porque o móbil principal que leva os homens a agir são "as paixões presentes do coração" ${ }^{40}$ Dessa forma, o argumento de que religiosos que não se comportem de acordo com seus princípios é por causa de seu "ateísmo escondido" (Id. Ibid.,p. 298.; Id. Ibid. $)^{41}$ torna-se implausível, já que justamente mandamentos religiosos não surtem efeito algum quando se trata de impedir que crimes sejam cometidos, seja contra partidários de uma doutrina contra outra, seja de uma nação contra outra. Bayle se questiona: se um determinado indivíduo sabe que matar ou roubar é proibido por um deus e se sua

que se tomava, não deixaram de cometer todos os crimes imagináveis."["Il faut bien que cela soit, puisque les anciens païens, accablés d'une multitude incroyable de superstitions, pérpétuellement occupés à apiser la colère de leurs idoles, épouvantés par une infinité de prodiges, imaginant que les dieux étaient les dispensateurs de l'adversité et de la prospérité selon la vie que l'on menait, n'ont pas laissé de commettre tous les crimes imaginables.’](2007, pp. 293-294; OD III[PD], p.88a. )

${ }^{38} P D, 2007$, p. 294; $O D$ III[PD], p. 88a. No original: "Et si cela n'était pas, comment serait-il possible que les chrétiens, qui connaissent si clairement par une révélation soutenue de tant de miracles qu'il faut renoncer au vice pour être éternellement heureux et pour n'être pas éternellment malhereux; qui ont tant d'excellents prédicateurs payés pour leur faire là-dessus les lus vives et les plus pressantes exhortations du monde; qui trouvent partout tant directeurs de conscience zélés et savants, et tant de livres de dévotion; comment, dis-je, serait-il possible, parmi tout cela, que les chrétiens vécussent, comme ils le font, dans les plus énormes dérèglements du vice?"

${ }^{39}$ PD, 2007, p. 297; OD III[PD], p. 89a. No original: “[...] Ce serait un travail infini que de s'amuser à éclaircir toutes les objections que l'on peut faire contre cette doctrine; car l'esprit humain étant capable de toutes les bizarreries imaginables, on ne posera jamais de règle sur son sujet qui ne souffre mille exceptions."

${ }^{40} P D, 2007$, p. 294; $O D$ III [PD], p. 89b, itálicos de Bayle. No original: "Ce qu'il y a donc à faire, c'est de s'en tenir à ce qui arrive le plus souvent, savoir que ce ne sont pas les opinions générales de l'esprit qui nous déterminent à agir, mais les passions présentes du coeur.' E a história, segundo Bayle, mostra o oposto: os ateus tinham as claras noções - na teoria e na prática - de honestidade, sensibilidade, bom temperamento: “[...]se Deus não nos tivesse deixado sem testemunho perante os próprios Ateus; se quis eles tivessem ele pelas ideias de honestidade civil, pela sensibilidade para o louvor, por um bom temperamento; se, em uma palavra, a história nos dá como um fato certo que seus costumes foram regrados, invejar-lhe-íamos esse pequeno bem? Escrutinarlhe-íamos por uma fraude piedosa?'[...si Dieu ne s'est point laissé sans témoignage envers les Athées mêmes; s'il a voulu qu'ils tinssent à lui par les idées de l'honnêteté civile, par la sensibilité pour la louange, par un bon tempérament; si en un mot l'Histoire nous donne comme un fait certain que leurs moeurs ont été réglées, leur envierons-nous ce petit bien? Les en dépouillerons-nous par une fraude pieuse? (OD III $[A P D]$, p. 178a.)

${ }^{41} P D, 2007$, p. 297; $O D$ III $[P D]$, p. 89b. No original: “On ne peut pas me répondre que les chrétiens qui ne vivent pas conformément aux principes de luer religion ne sont pas persuadés de nos nystères, et que sont autant d'athées cachés."

\begin{tabular}{|c|c|c|c|c|c|}
\hline intuitio & $\begin{array}{c}\text { ISSN } \\
1983-4012\end{array}$ & Porto Alegre & Vol.7 $-\mathrm{N}^{\mathrm{o}} .2$ & $\begin{array}{c}\text { Novembro } \\
2014\end{array}$ & p. 172-183 \\
\hline
\end{tabular}


índole não vê nenhuma bondade em cometer tais ações, ou se o temor pela má reputação e castigo poderia impedi-lo, por que, a despeito de todos esses fatores, se é levado ao crime? Ou em outros termos, "se as luzes da consciência fossem a razão que nos determina, os cristãos viveriam tão mal como o fazem?" ${ }^{42}$ O que o filósofo de Carla quer dizer é que, se as persuasões do espírito de forma geral não são o motor das ações humanas, mas as paixões particulares - como por exemplo, o costume e o temperamento - pode ocorrer uma descontinuidade enorme entre o que se crê e o que se faz. ${ }^{43}$ Podendo parecer anormal, em termos conjecturais, que alguém que não creia em nada possa ter uma vida imaculada moralmente, contudo, é digno de mais estranheza ainda ipso facto que o homem, criatura racional por excelência, aja somente esporadicamente de acordo com o que crê. ${ }^{44}$

Segundo Bayle, o princípio que faz com que ateus e idólatras sejam levados a fazer o mal ou o bem não é a crença ou descrença na existência de uma providência divina que puna os maus e recompense os bons. Tais princípios das ações humanas são de cunho externo e interno, a saber, a propensão do temperamento e pela influência dos hábitos adquiridos:

Pois, se a persuasão que há uma providência divina que castiga os maus e que recompensa as pessoas de bem não é o princípio das ações particulares do homem, como eu venho a mostrar, segue-se que um ateu e um idólatra governam-se por um mesmo princípio no tocante aos costumes, isto é, pelas inclinações de seu temperamento e pelo peso dos hábitos que eles contraíram. De sorte que, para saber qual dos dois deve ser pior do que o outro, somente é preciso investigar as paixões às quais eles sujeitaram-se. ${ }^{45}$

${ }^{42} P D, 2007$, p.297-298; $O D$ III[PD], p. 89b. No original: "Encore um coup, si les lumières de la conscience étaient la raison qui nous détermine, les chrétiens vivraient-ils aussi mal qu'ils font?" No $C P h$, Bayle diz: "E esta regra não pôde ser outra coisa que a luz natural, que os sentimentos de honestidade impressos na alma de todos os homens; em uma palavra, que esta razão universal que esclarece todos os espíritos e que não falta jamais àqueles que a consultam atentamente, e sobretudo, nesses intervalos lúcidos, onde os objetos corporais não preenchem a capacidade da alma, seja por suas imagens, seja pelas paixões que elas excitam em nosso coração." ["Et cette règle n'a pu être autre chose que la lumière naturelle, que lessentiments d'honnêteté imprimés dans l'âme de tous les hommes; en un mot que cette raison universelle qui éclaire tous les esprits et qui ne manque jamais à ceux qui la consultent attentivement, et surtout dans ces inervalles lucides, où les objets corporels ne remplissent pas la capacité de l'âme, soit paer leurs images, soit par les passions qu'ils excitent dans notre coeur.'] (1992, I, i, p. 92; OD II[CPh], p. 369b).

${ }^{43}$ Daí, Bayle reverte a argumentação, isto é, do mesmo jeito que um ateu pode agir corretamente por seu temperamento, um idólatra pode agir desregradamente: "Então é tão fácil que um ateu se prive de seus prazeres em favor de um outro como é fácil que um idólatra faça um falso sermão. Assim, se vê que de um homem que não tenha religião alguma, não se segue necessariamente que ele se entregue a toda espécie de crimes ou a toda espécie de prazeres." ["Donc il est facile qu'un athée se prive de ses plaisirs en faveur d'un autre qu'ils est facile qu'un idolâtre fasse un fausse serment. Ainsi, l'on voit que, de ce qu'un homme n'a point de religion, il ne s'ensuit pas nécessairement qu'il se porte à toute sorte de crimes ou à toute sorte de plaisirs."](2007, p. 371; OD III[PD], p. $113 b)$.

44 "Concebo que é uma coisa bem estranha que um homem que viva bem moralmente e que não creia nem no Paraíso nem no inferno. Mas eu retorno sempre aí, que o homem é uma certa criatura que, com toda a sua razão, não age sempre conforme a sua crença Os cristãos nos fornecem muitas provas." "Je conçois que c'est une chose bien étrange qu'un homme qui vit bien moralement et qui ne croit ni Paradis ni Enfer. Mais j'en reviens toujours là, que l'homme est une certaine créature qui, avec toute sa raison, n'agit pas toujours conséquemment à sa créance. Les chrétiens nous fournissent assez de preuves.](BAYLE, 2007, p. 370; OD III[PD], p. 113a).

${ }^{45} P D, 2007$, p. 308; $O D$ III $[P D]$, p. 93a. No original:“Car si la persuasion qu'il y a une providence qui châtie les méchants et qui recompense les gens de bien n'est pas le ressort des actions particulières de l'homme, comme jê viens de le faire voir, il s'ensuit qu'un athée et qu'un idolatre se gouvernent par um même príncipe pour ce qui

\begin{tabular}{|c|c|c|c|c|c|}
\hline intuitio & $\begin{array}{c}\text { ISSN } \\
1983-4012\end{array}$ & Porto Alegre & Vol.7 $-\mathrm{N}^{\mathrm{o}} .2$ & $\begin{array}{c}\text { Novembro } \\
2014\end{array}$ & p. 172-183 \\
\hline
\end{tabular}


Isto é, agir bem ou mal não é mais questão de crença ou descrença. Diversos fatores podem influenciar a motivação de uma determinada ação, seja para ateus seja para idólatras. Tanto o temperamento, isto é, a propensão a fazer certas coisas como os hábitos que foram assimilados são o que o mobilizam o homem a concretizar as mais diversas ações. Nesse sentido, o critério da crença em uma providência divina reguladora do curso da natureza e julgadora das ações humanas para saber os motivos que levaram um homem a agir de uma forma ou de outra dá lugar à necessidade de uma investigação sobre os móbeis de caráter interno - fisiológicos ou psicológicos - e de caráter externo sociais e educacionais. Análises genéricas sobre o que impulsiona os homens a agirem, isto é, somente afirmar que se age mediante as paixões é superficial, perdendo-se a complexidade do problema. Bayle dá um exemplo:

Quando se examinam essas coisas com uma visão geral, imagina-se que desde que
um ateu pense que podendo embriagar-se impunemente, ele embriaga-se todos os
dias. Mas aqueles que sabem a máxima trahit sua quemque voluptas [cada um é
impulsionado por sua paixão], e que examinaram mais exatamente o coração do
homem não vão tão rápido. Eles informam-se antes de julgar a conduta deste ateu,
qual é seu gosto. Se eles veem que ele gosta de beber, que é bastante sensível a este
prazer, que ele gosta mais do que da reputação de homem honesto, julgam
efetivamente que ele bebe o tanto que puder. Mas eles não julgam por isso que ele o
faz mais que uma infinidade de cristãos que são bêbados por quase toda a sua vida. ${ }^{46}$

Eis a lição bayleana deste curioso exemplo: em todo e qualquer assunto que exija reflexões mais complexas e acuradas, é preciso informar-se minimamente a respeito, isto é, examinar antes de julgar. O exemplo aqui do apreço de um ateu aos prazeres da bebida, por si só, não permite julgar temerariamente ou moralmente acerca dos motivos que o levam a tal postura. Faz-se necessário, Bayle diz, no mínimo saber sobre suas preferências, isto é, ter conhecimento das condições prévias que o levaram à compulsão por beber e, da mesma forma, a respeito de toda ação que ele viria a fazer. A ironia no final da passagem é evidente: somente em ver um ateu mergulhado na embriaguez, críticos mais apressados esqueceriam da grande quantidade de cristãos que permanecem ébrios por uma vida inteira, sem levar em conta o que fez com que chegassem a tal condição. Mas o mais importante é a conclusão de Bayle, pois isto é uma "grande prova que o espírito de deboche não depende das opiniões que se tem ou não no tocante à natureza de Deus $[\ldots . .$, "47

regarde les moeurs, c'est-à-dire par les inclinations de leur tempérament et par le poids des habitudes qu'ils contractées. De sorte que, pour trouver lequel des deux doit être plus méchant que l'autre, il ne faut que s'enquérir des passions auxquelles leur tempérament les assujettit."

${ }^{46} P D, 2007, \mathrm{pp} .308-309 ; O D \mathrm{III}[P D], \mathrm{p} .93 a$. No original: "Quand on n'examine ces choses que d'une vue générale, on se figure que dês qu'un athée fait réfléxion qu'il peut s'enivrer impunément, il s'enivre tous les jours. Mais ceux qui savent la máxime trahit sua quemque voluptas et qui ont examine plus exactement le coeur de l'homme ne von pás si vite. Ils s'informent, avant que de juger de la conduite de cet athée, quel est son goût. S'ils trouvent qu'il aime à boire, qu'il est fort sensible à ce plaisir-là, qu'il en est plus friand que de la réputation d'honnête homme, ils jugent qu'effectivement il boit autant qu'il peut. Mais ils ne jugent pás pour cela qu'il en fait plus qu'une infinite de chrétiens qui sont saouls presque toute leur vie."

${ }^{47} P D, 2007$, p.308-309; $O D$ III[PD], p.93a. No original:“Grande preuve que l'esprit de débauche ne dépend pas des opinions que l'on a ou que l'on n'a pas touchant la nature de Dieu[...]"

\begin{tabular}{|c|c|l|l|l|l|}
\hline intuitio & $\begin{array}{c}\text { ISSN } \\
1983-4012\end{array}$ & Porto Alegre & Vol.7- N $^{\circ} .2$ & $\begin{array}{c}\text { Novembro } \\
2014\end{array}$ & p. 172-183 \\
\hline
\end{tabular}


Bayle desenvolve mais sua argumentação. Se quisessem lançar-lhe uma objeção, isto é, que esse princípio poderia ser mais facilmente e melhor corrigido nos idólatras do que nos ateus, o filósofo de Carla recorre à experiência. Ele questiona porque os idólatras mais supersticiosos não conseguiram ou pouco avançaram em extirpar esse erro de si mesmos:

Que me objetem tanto quanto queiram que o temor a um Deus seja um meio infinitamente apropriado para corrigir esta corrupção natural, eu apelarei sempre à experiência e sempre perguntarei por que então os pagãos que levavam o temor a seus deuses até superstições tão excessivas tão pouco corrigiram esta corrupção que não há vício abominável que não tenha reinado entre eles. ${ }^{48}$

Consultando a experiência, parece que o recurso a um deus fictício como repressor e freio das paixões humanas surtiu um efeito contrário: tal artifício culminou e desencadeou as mais absurdas superstições, engendrando e disseminando toda sorte de vícios. Contudo, se Bayle afirma que tal corrupção é natural, não seria natural a todos os homens, isto é, a idólatras e a ateus? Uma possível resposta seria a seguinte: no caso de cometerem um perjúrio, os ateus fariam sem o hesitar, não temendo punição alguma de uma justiça invisível. Os idólatras, ao contrário, se o fizessem, sê-lo-ia com medo de uma represália celeste, imaginando que a vingança os persegue por toda parte, mas por outro lado, mesmo a despeito deste temor, continuariam blasfemando desde que a ocasião se apresentasse. Não haveria contradição alguma na postura do ateu, pois para ele não há instância divina alguma que o condene e o faça arrepender-se de uma determinada ação cometida, em outras palavras, ele nada deverá e nem incorrerá em contradição com seus preceitos morais. Contrariamente, para o idólatra, tendo conhecimento desde sempre de que suas ações são condenáveis pelo deus que crê, continua agindo temerariamente conduzido por suas paixões. ${ }^{49}$ Para Bayle, isto é uma questão de fato:

Vemos reinar ainda por toda parte esta espécie de espírito que encerra os homens no pecado, não obstante o temor dos infernos e os remorsos da consciência. [...] Se é então verdadeiro, como a história e o curso da vida comum o justificam, que os homens podem mergulhar em toda sorte de crimes enquanto estão persuadidos da verdade de sua religião que lhes ensina que Deus castiga severamente o pecado e que recompensa magnificamente as boas obras; é preciso concordar que para os que nos dão esta persuasão como uma prova e como uma justificação de boa vida

\footnotetext{
${ }^{48} P D$, 2007, p. 309; $O D$ III $[P D]$, p. 93b. No original:“Qu'on m'objecte tant qu'on voudra que la crainte d'un Dieu est un moyen infiniment propre à corriger cette corruption naturelle, j'en appellerai toujours à l'expérience et jê demanderai toujours pourquoi donc les païens qui portaient la crainte de leurs dieux jusqu'à des superstitions excessives ont si peu corrige cette corruption qu'il n'y a point de vice abominable qui n'ait régné parmi eux."

${ }^{49}$ É o que afirma Holbach, citando Bayle: "O ateu, quando comete crimes, não pode ao menos pretender que foi o seu deus que o ordena e que o aprova. É a desculpa que, todos os dias, o supersticioso dá para a sua maldade, o tirano para as suas perseguições, o sacerdote para a sua crueldade e para a sua sedição, o fanático para os seus excessos e o penitente para a sua inutilidade. 'Não são', diz Bayle, 'as opiniões gerais do espírito que nos determinam a agir, mas as paixões.' $\mathrm{O}$ ateísmo é um sistema que, de um homem honesto, não fará nunca um perverso e que, de um homem perverso, não fará um homem de bem." HOLBACH, Barão de. Sistema da natureza ou das leis do mundo físico e do mundo moral. Trad. de Regina Schöpke e Mauro Baladi. São Paulo: Martins Fontes, 2010, II, xii, p. 797.
}

\begin{tabular}{|c|c|c|c|c|c|}
\hline intuitio & $\begin{array}{c}\text { ISSN } \\
1983-4012\end{array}$ & Porto Alegre & Vol.7- $\mathrm{N}^{\mathrm{o}} .2$ & $\begin{array}{c}\text { Novembro } \\
2014\end{array}$ & p. 172-183 \\
\hline
\end{tabular}


enganam-se necessariamente, e que, assim, é mal raciocinar concluir que um homem que é idólatra viva melhor do que um ateu. ${ }^{50}$

A história e a vida ordinária o confirmam. È manifesta a discordância entre os temores internos dos idólatras e sua extravagância nas ações. Por vezes, o que uma religião ensina é irrelevante quando as paixões falam mais alto, fazendo com que o indivíduo enverede pelo caminho dos atos mais violentos e desmedidos. E o pior, tentar fazer com que essa postura paradoxal dos idólatras sirva tanto de fundamento e justificativa para uma vida boa, como tentar fazer de argumento contra a moralidade dos ateus. A esse falso raciocínio, Bayle opõe a experiência: é só dar uma consultada historicamente dos feitos dos idólatras para chegar à conclusão de que eles, ao invés de se sentirem impedidos pelo temor e respeito aos seus deuses e à sua justiça, eles os desprezaram, fazendo tudo que seja contrário aos seus preceitos religiosos. Bayle volta ao argumento inicial: a tendência a fazer o mal - ou o bem nada tem a ver com o conhecimento ou desconhecimento, com a presença ou ausência da noção de um deus no espírito do homem. É a sua natureza, fortalecida pelas paixões as quais têm sua origem no temperamento, que compelem o homem à ação, suscetíveis de serem modificadas conforme circunstâncias externas e fortuitas:

Resulta daí manifestamente que a inclinação a fazer o mal não se encontra mais em
uma alma destituída do conhecimento de Deus do que em uma alma que conhece
Deus; e que uma alma destituída do conhecimento de Deus não é mais despojada do
freio que reprime a maldade do coração do que uma alma que tem esse
conhecimento. Daí ainda resulta que a inclinação a fazer o mal vem do fundo da
natureza do homem e que ela fortifica-se pelas paixões que, saindo do temperamento
como de sua origem, em seguida modificam-se de diversas maneiras, segundo os
diversos acidentes da vida. Enfim, daí resulta que a inclinação à piedade, à
sobriedade, à mansidão, etc., não vem do que se conheça que há um Deus (pois, de
outra maneira, precisar-se-ia dizer que jamais existiu pagão cruel e bêbado), mas de
uma certa disposição do temperamento, fortificada pela educação, pelo interesse
pessoal, pelo desejo de ser louvado, pelo instinto da razão, ou por semelhantes
motivos que se encontram em um ateu tanto como nos outros homens. Assim, não
temos nenhum direito de sustentar que um ateu deva necessariamente ser mais
desregrado em seus costumes do que um idólatra.

${ }_{50} P D, 2007$, pp.310-311; OD III $[P D]$, p. 93b. No original:"Nous voyons régner encore partout cette sorte d'esprit qui entraîne les hommes dans le péché, nonobstant la crainte des enfers et les remords de la conscience.[...] S'il est donc vrai, comme l'histoire et le train de la vie commune le justifient, que les hommes se peuvent plonger dans toute sorte de crimes pendant qu'ils sont persuades de la vérité de luer religion qui leur enseigne que Dieu châtie sévèrement le péché et qu'il recompense magnifiquement les bonnes oeuvres; il faut tomber d'accord que pour ceux qui nous donnent cette persuasion pour une preuve et pour un titre justificatif de bonne vie se trompent nécessairemente, et qu'ainsi c'est mal raisonner que de conclure de ce qu'un homme est idolatre qu'il vit moralement mieux qu'un athée."

${ }^{51} P D, 2007$, pp. 311-312; OD III $[P D]$, p. 94a. No original: "Il resulte de là manifestement que l'inclination à mal faire ne se trouve pás plus dans une ame destituée de la connaissance de Dieu que dans une ame qui connaît Dieu; et qu'une ame destituée de la connaissance de Dieu n'est pás plus dégagée du frein qui reprime la malignité du coeur qu'une ame qui a cette connaissance. Il resulte encore de là que l'inclination à mal faire vient $\mathrm{du}$ fonde de la nature de l'homme et qu'elle se fortifie par les passions qui, sortant du tempérament comme de leur source, se modifient ensuite de plusieurs manières, selon les divers accidents de la vie. Enfin il resulte de là que l'inclination à la pitié, à la sobriété, à la débonnaireté, etc., ne vient pás de ce qu'on connaît qu'il y a un Dieu (car autrement il faudrait dire que jamais il n'y a eu de païen cruel et ivrogne), mais d'une certaine disposition du tempérament, fortifiée par l'éducation, par l'intérêt personnel, par le désir d'être loué, par l'instinct de la raison,

\begin{tabular}{|c|c|c|c|c|c|}
\hline intuitio & $\begin{array}{c}\text { ISSN } \\
1983-4012\end{array}$ & Porto Alegre & Vol.7 - No.2 & $\begin{array}{c}\text { Novembro } \\
2014\end{array}$ & p. 172-183 \\
\hline
\end{tabular}


Sendo o temperamento o leitmotiv das ações humanas, que faz com que o homem cometa o mal, tendo em consideração fatores externos que possam influenciar na execução de um determinado ato, isso também vale no tocante a fazer o bem. Segundo Bayle, os mesmos motivos que fazem tender para os maus sentimentos fazem tender para os bons. Uma disposição do temperamento que, fortalecida por fatores de ordens diversas, pode ser encontrada tanto no ateu, como em qualquer outro homem, Bayle desvalida de vez o argumento que uma ação boa ou má dependa da crença ou descrença de quem a executa. A natureza humana é tão propensa ao mal como ao bem, dependendo da intensidade ou da calmaria das paixões e da direção que elas tomem, pois em todos os homens inclusive o ateu - há o que Bayle chama de instinto da razão. Nesse sentido, se o "freio" dos idólatras é o seu deus regulador dos pensamentos e das ações - nem sempre eficaz - o do ateu é o apreço à bondade, à virtude, à retidão nas ações, isto é, a sentimentos que independem da crença em uma divindade. A corrupção da natureza humana aqui, de certa forma, é atenuada à medida que Bayle assume que o temperamento aliado a outros motivos pode também levar a agir retamente. Logo, é impossível sustentar que ateus sejam mais depravados do que os idólatras em matéria de costumes.

Bayle estabelece a comparação da disposição do coração dos idólatras com a dos ateus. Estes últimos, não sendo inpedidos pelo medo de um castigo divino e tampouco movidos pela esperança de uma recompensa dos céus, não se entregam absolutamente à sedução proporcionada por suas paixões. Ele diz nos Pensées diverses:

Se observarmos os ateus na disposição de seu coração, vemos que, nem sendo retidos pelo medo de nenhum castigo divino nem animados pela esperança de nenhuma bendição celeste, eles devam abandonar-se a tudo que lisonjeia suas paixões. É tudo que podemos dizer, não tendo os anais de nenhuma nação ateia. Se tivéssemos, saberíamos até que excesso de crimes chegam os povos que não reconhecem nenhuma divindade, se eles vão mais longe do que aquelas que reconheceram um número inumerável. Creio que esperando uma relação bem fiel dos costumes, das leis e hábitos desses povos que se diz que não professam nenhuma religião, pode-se assegurar que os idólatras fizeram em matéria de crimes tudo o que saberiam fazer os ateus. ${ }^{52}$

Equiparadas as disposições ou móbeis que levam tanto ateus como idólatras a agirem, Bayle mostra que nem sempre os ateus são guiados por suas paixões, mesmo na falta de estudos e descrições mais detalhadas a respeito das leis e costumes dos habitantes de uma sociedade ateia e até que ponto chegariam as suas atrocidades - relatos antropológicos dos quais Bayle se valerá na Continuation.

ou par de semblables motifs que se rencontrent dans um athée aussi bien que dans les autres hommes. Ainsi nous n'avons aucun droit de soutenir qu'un athée doit être nécessairement plus déreglé dans seus moeurs qu'un idolatre."

${ }^{52} P D, 2007$, p. 279; $O D$ III $[P D]$, p. 83a. No original: "Se l'on regarde les athées dans la disposition de leur coeur, on trouve que, n'étant ni retenus par la crainte d'aucun châtiment divin, ni animes par l'espérance d'aucune bénédiction celeste, ils doivent s'abandonner á tout ce qui flatte leurs passions. C'est tout ce que nous en pouvons dire, n'ayant point les annales d'aucune nation athée. Si nous en avions, on saurait jusqu'à qul excès de crimes se portent les peoples qui ne reconnaissent aucune divinité, s'ils vont beaucoup plus loin que celles qui en ont reconnu un nombre innombrable. Je crois qu'en attendant une relation bien fidèle des moeurs, des lois et des coutumes de ces peoples que l'on dit qui ne professent aucune religion, on peut assurer que les idolâtres on fait en matière de crimes tout ce qu'auraient su faire les athées."

\begin{tabular}{|c|c|c|c|c|c|}
\hline intuitio & $\begin{array}{c}\text { ISSN } \\
1983-4012\end{array}$ & Porto Alegre & Vol.7 $-\mathrm{N}^{\circ} .2$ & $\begin{array}{c}\text { Novembro } \\
2014\end{array}$ & p. 172-183 \\
\hline
\end{tabular}


Contudo, se ainda é obscuro o conhecimento a respeito de uma nação em que a crença na existência de um deus é insignificante, é fato que o "número inumerável" citado por Bayle de crimes que foram reconhecidos no decorrer dos tempos é atribuído aos idólatras. Sendo certo que idólatras cometeram toda espécie de crimes no decorrer dos tempos, em relação aos ateus tal postura ainda é algo condicional, ou seja, não se sabendo nada ainda sobre eles, não é possível nada afirmar ou negar quanto à sua potencialidade criminal: o que "fizeram" os idólatras, "saberiam" fazer os ateus. No mesmo parágrafo, Bayle recorre à história e arremata:

E se lermos as histórias profanas e os outros monumentos que nos restam da Antiguidade, ver-se-á evidentemente tudo o que a mais brutal e a mais desnaturada luxúria, a mais desenfreada ambição, o ódio e o mais negro desejo, a avareza mais insaciável, a crueldade mais feroz, a perfídia mais estranha podem fazer executar a um ateu professo foi efetivamente executado pelos antigos pagãos, adoradores de quase tantas divindades como tinha de criaturas. ${ }^{53}$

A recorrência de Bayle aos fatos históricos não deixa dúvida a respeito de quem cometeu mais atrocidades, movidos pelas paixões. Desde os tempos mais remotos, registrados nos mais diversos escritos da antiguidade, a constatação de que os idólatras sempre foram criminosos implacáveis salta à vista. Basta fazer uma incursão no passado para ver o quanto de crimes foram permitidos e consumados por paixões desenfreadas dos adoradores de ídolos, valendo-se dos meios mais absurdos para efetivá-los e para alcançar fins mais repugnantes ainda. Todavia, a mesma história nada mostrou acerca da consequência desse fervor das paixões em relação aos ateus. Prestemos atenção nos termos e expressões usados por Bayle: se esses mesmos móbeis desencadeadores de ações temerárias "podem fazer", isto é, hipoteticamente, com que um ateu faça uma ação hedionda, "efetivamente", isto é, pelos próprios fatos, os idólatras fizeram tudo o que há de mais inconcebível devido às suas paixões. Segundo Bayle, um argumento poderia lhe ser objetado, a saber, que esses idólatras criminosos, na verdade, eram ateus na alma, contudo, "seria absurdo pretender que eles não reconheçam nenhum deus. Isto pode ser verdadeiro de alguns, mas é muito falso no maior número, como eu provar-vos-ei invencivelmente". ${ }^{4}$ Bayle cita o exemplo de Nero que, segundo o historiador Suetônio, tinha medo e reconhecia uma justiça divina que supostamente viria a ter com ele quando desprezava certas cerimônias religiosas. Era atormentado por remorsos na consciência e aterrorizado com sonhos de mau agouro, e, por outro lado, ele fazia reverência piamente aos céus quando era contemplado. Seu comportamento sendo oscilante quanto a outras superstições, ele ficava até o fim cultuando uma pequena imagem de uma criança a qual ele sacrificava periodicamente e que, pouco antes de morrer,

\footnotetext{
${ }^{53} P D, 2007$, p.279; $O D \operatorname{III}[P D]$, p. 83a. No original: "Et si on lit les histoires profanes et les autres monuments qui nous restent de l'Antiquité, on verra évidemment que tout ce que la plus brutale El la plus denature paillardise, la plus effrénée ambition, la haine et l'envie la plus noire, l'avarice la plus insatiable, la cruauté la plus féroce, la perfidie la plus étrange peuvent faire executer à un athée profess a été effectiovement execute par les anciens païens, adorateurs de Presque autant de divinités qu'il y avait de creatures."

${ }^{54} P D, 2007$, p. 280; $O D$ III $[P D]$, p. 83b. No original: "il serait absurde de prétendre qu'ils ne reconnaisent aucun dieu. Cela peut être vrai de quelques-'uns, mais il est três faux de plus grand nombre, comme jê vous prouverai invinciblement."

\begin{tabular}{|c|c|c|c|c|c|}
\hline intuitio & $\begin{array}{c}\text { ISSN } \\
1983-4012\end{array}$ & Porto Alegre & Vol.7- $\mathrm{N}^{\circ} .2$ & $\begin{array}{c}\text { Novembro } \\
2014\end{array}$ & p. 172-183 \\
\hline
\end{tabular}
}


ele ficava mexendo nas entranhas das vítimas. Daí a conclusão de Bayle: "Ele não era ateu." segundo exemplo é o de Heliogábalo. Este era tão ferrenho em seu culto ao deus que ele tinha sido consagrado padre, que levou ao templo que ele tinha abatido em Roma tudo o que tinha de mais sacro nos outros. Chegou mesmo a mencionar que era preciso levar todas as religiões existentes a este templo para que o culto ao seu deus englobasse o de todos os outros. Da mesma forma, imolava todas as manhãs um considerável número de vítimas, sacrificava as mais belas crianças que pudesse encontrar na Itália, e durante a imolação das vítimas, ele orava a seus ídolos e ele mesmo observava as hóstias por dentro para aí entrever os presságios de seus êxitos. Sendo assim, Bayle infere: "Tudo isso prova tão fortemente que esse detestável monstro não era ateu como não é necessário alegar que a credulidade que ele teve para com os que predizeram-lhe que morreria de morte violenta". ${ }^{56}$

E, em se tratando de assuntos de ordem factual, visando a desmistificar o valor consensual de uma opinião, é primordial o recurso à história, por meio de fatos, exemplos, razões a posteriori. Na Continuation, Bayle diz, por exemplo, que um exame da história antiga fará perceber que é "muito pouco verossímil que a religião tenha servido de freio aos maiores perturbadores da paz pública" ${ }^{, 57}$ já que "se imagina falsamente que um homem aja segundo seus princípios, isto é, segundo o que ele crê em matéria de religião." ${ }^{, 58} \mathrm{Em}$ uma de suas inúmeras respostas às acusações de Jurieu, Bayle, nas Additions, diz que seu algoz não poderia concluir que o ateísmo é sinônimo de vício, sem se "[...] inscrever em falso contra fatos que têm todos os caracteres de certeza que se podem exigir nessas matérias" ${ }^{59}$ A projeção de preconceitos particulares na análise e crítica dos fatos históricos é também um difícil empecilho a ser superado, visto que pela própria história, esses mesmos preconceitos seriam denunciados, trazendo à tona a afetação de quem relata os acontecimentos. No "Esclarecimento sobre os ateus" ${ }^{, 00}$, de seu Dictionnaire historique et critique, Bayle diz:

Para tirar inteiramente as suspeitas de uma afetação viciosa, tive o cuidado de observar $^{61}$ todas as vezes que pude os maus costumes dos Ateus. Se eu não o fiz

\footnotetext{
${ }^{55} P D, 2007$, p. 280; $O D$ III $[P D]$, p. $83 b$. No original:“Il n’était pás athée.”

${ }^{56} P D, 2007$, p. 281; $O D$ III $[P D]$, p. $83 b$. No original: "Tout cela prouve si fortement que ce détestable monstre n'était pás athée qu'il n'est pás besoin d'alleguer la crédulité qu'il eut pour ceux qui lui avaient prédit qu'il mourrait de mort violente."

${ }^{57} O D$ III $[C P D]$, p.357b. No original: "Si nous parcurions les plus notables morceaux de l'histoire ancienne, nous trouverions qu'il est très-peu vraisemblable que la Religion ait servi de frein aux plus grands perturbarteurs du repos public."

${ }^{58} P D, 2007$, p. 372;OD III $[P D]$, p. 113b. No original: “C'est qu'on s'imagine faussement qu'un homme agit toujours selon ses principes, c'est-à-dire selon ce qu'il croit en matière de religion."

${ }^{59} O D$ III $[A P D]$, p.182b, grifo meu. No original: “[...] sans vous inscrire en faux contre des faits qui ont tous les caracteres de certitude qu'on peut demander en ces matières."

${ }^{60}$ Ver a minha tradução do texto na íntegra in: Revista Conatus: Filosofia de Spinoza. Fortaleza: Ed. da UECE, julho 2009, vol. 3, n ${ }^{\mathrm{o}} 5$, pp. 109-113.

${ }^{61}$ Um estudo mais detalhado acerca da definição de observação bayleana, ver BIANCHI, L. "Do Dictionnaire de Bayle à Encyclopédie de Diderot” In: SKEPSIS. São Paulo: Unifesp, 2009, volume III, nº5, pp. 183-200. (tradução de minha autoria) Quanto à influência das paixões no relato de fatos históricos, o destinatário da crítica de Bayle é Jurieu, uma vez que recusar que ateus viveram corretamente é agir em nome de um utilitarismo religioso jamais comprometido com a verdade dos fatos: "Queriam então que eu diga que os costumes dos Ateus jamais foram segundo as regras? Queriam então que eu debitasse uma falsidade e que eu opusesse uma ficção de meu cérebro a testemunhos irreprováveis. Queriam então que eu me enrede sobre esses fatos, com medo de
}

\begin{tabular}{|c|c|c|c|c|c|}
\hline intuitio & $\begin{array}{c}\text { ISSN } \\
1983-4012\end{array}$ & Porto Alegre & Vol.7- $\mathrm{N}^{\mathrm{o}} .2$ & $\begin{array}{c}\text { Novembro } \\
2014\end{array}$ & p. 172-183 \\
\hline
\end{tabular}


com mais frequência, foi devido somente à falta de matéria. O Público soube que exigi que me indicassem exemplos; ninguém se deu a esse trabalho e eu ainda não pude nada descobrir por minhas buscas. ${ }^{62}$ (1740, XIII, p. 111; 2010, p. 18.)

Bayle assevera que suas investigações históricas não deram o aval para se poder afirmar que o ateísmo sempre foi acompanhado de atrocidades no decorrer dos tempos. O filósofo exigira exemplos de tal associação, e, não obtendo resposta, ficou impossibilitado de dar uma tintura ortodoxa à imagem dos ateus na história. ${ }^{63}$ Nesse sentido, relatar que existiram ateus virtuosos em nada denigre a religião, porém, "omitir-se de falar não teria sido conforme ao dever do historiador". ${ }^{64}$ Nos Pensées diverses, Bayle aponta para algo mais além do que propriamente como o historiador deva proceder perante aos fatos históricos: ele toca na jugulum causae da questão, ou seja, desconstruir a opinião de que a religião é a base das relações sociais ${ }^{65}$, trabalho a ser feito tanto através da filosofia, como por meio de uma investigação crítica da história. Ora, se Bayle tanto insistiu sobre a fragilidade da opinião no que concerne à apreciação sobre questões de fato, é porque a contraprova cabal é a história. Bayle diz na Continuation: "Não tenho necessidade de nenhum lugar comum, os fatos bastam-me." ${ }^{, 66}$ Frase incisiva, pois se o lugar-comum é a opinião, um olhar minucioso sobre os acontecimentos factuais permite desconstruir o aparato argumentativo e impositivo de uma tradição interessada em permanecer nos meandros da pluralidade dos sufrágios, e, através desse critério, denegrir a imagem dos ateus. Aliada à crítica, a história torna-se o instrumento de revista, com a tarefa de investigar cada detalhe e dispensando hipóteses que não levem em conta a experiência. Verdades de fato não podem ser omitidas nem substituídas por artifícios de retórica, elucubrações metafísicas ou por opiniões advindas da pluralidade das vozes. Dessa forma, essa é a exigência de Bayle: a necessidade de uma investigação incessante e crítica da validade e legitimidade de opiniões que, em todos os lugares e épocas, surgiram e se disseminaram ganhando estatuto de verdade. Nessa empreitada, história e crítica coadunam-se, pois se a primeira é a ciência dos fatos, a última é que vai por à prova a veracidade e consistência dos relatos desses mesmos fatos.

diminuir o horror que se tem pelo Ateísmo?" "Vouloit-on que je dise que jamais les moeurs d'un Athée n'ont été selon les règles? On vouloit donc que je débitasse une fausseté, \& que j'opposaisse une fiction de mon cerveau à des témoignages irréprochables. Vouloit-on que je me tusse sur ces faits, de peur de diminuer l'horreur que l'on inspire de l'Athéisme?'] (OD III[APD], 177b., grifos meus.)

${ }^{62}$ ESA, 1740, XIII, p. 111; 2010, p. 18. No original: "Pour ôter entièrement les soupçons d'une affectation vicieuse, j'ai eu soin de remarquer toutes les fois que je l'ai pu les mauvaises moeurs des athées. Si je ne l'ai pas fait plus souvent, ce n'est qu'à cause que la matière m'a manqué.Le public a su que j'ai demandé qu'on m'indiquait des exemples; personne n'a pris cette peine, \& je n'ai pu encore rien déterrer par mes recherches."

${ }^{63} \mathrm{Na} C P D$, Bayle retorque a argumentação daqueles que usam de argumentos de autoridade para refutar a honestidade dos ateus, isto é, ele usa das mesmas autoridades para refutar seus opositores. Cf. precisamente os parágrafos LXXVI-LXXVII.

${ }^{64}$ BOST, H. Pierre Bayle. Paris: Fayard, 2006, p. 451.

${ }^{65}$ Cf. $C P D$, CXXIV

${ }^{66} O D$ III[CPD], p. 305a. No original: "Je n'ai besoin d'aucun lieu commun, les faits me suffisent."

\begin{tabular}{|c|c|l|l|c|c|}
\hline intuitio & $\begin{array}{c}\text { ISSN } \\
1983-4012\end{array}$ & Porto Alegre & Vol.7- $\mathrm{N}^{\mathrm{o}} .2$ & $\begin{array}{c}\text { Novembro } \\
2014\end{array}$ & p. 172-183 \\
\hline
\end{tabular}




\section{Referências}

BAYLE, P. Euvres diverses. La Haye: Compagnie des Librairies, 1737, 4 tomes. Paris: Hachette BnF, 2012.

Continuation des pensées diverses, écrites a un Docteur de Sorbonne, à l'occasion de la Comète qui

parut au móis de Décembre de 1680 ou Réponse a plusieurs dificultez que Monsieur *** a proposées à l'Auteur. Amsterdam: Herman Uytwerf, tome II, s.d.p. (versão fac-símile).

"Esclarecimento sobre os ateus". in: Revista Conatus: Filosofia de Spinoza. Fortaleza: Ed. da UECE, julho 2009, vol. 3, n 5 , pp. 109-113.

Pensées diverses sur la comète. Paris: Librairie E. Droz, 1939, 2 vol.

. Pensées diverses sur la comète. Paris: Flammarion, 2007.

BIANCHI, L. "Do Dictionnaire de Bayle à Encyclopédie de Diderot" In: SKEPSIS. Trad. de Marcelo de Sant'Anna Alves Primo. São Paulo: Unifesp, 2009, volume III, nº5, p. 183-200.

BINOCHE, B. “Croyances privées, opinion publique”, In: Revue Philosophique de Louvain. Louvain: 2010, p. 617-638.

BOST, H. Pierre Bayle. Paris: Fayard, 2006.

/McKENNA, Antony. Les "Éclaircissements" de Pierre Bayle. Paris: Honoré Champion, 2010.

DELPLA, I; DE ROBERT, P. La raison corrosive: études sur la pensée critique de Pierre Bayle. Paris: Honoré Champion, 2003.

Ver DUBOIS, J. et alii. Dictionnaire du français classique: XVIIe siècle. Paris: Larousse, 1988 (Références Larousse).

HOLBACH, P.H.T. Sistema da natureza ou das leis do mundo físico e do mundo moral. Trad. de Regina Schöpke e Mauro Baladi. São Paulo: Martins Fontes, 2010.

HUME, D. História natural da religião. Tradução, apresentação e notas de Jaimir Conte. São Paulo: UNESP, 2005.

JORINK, E. "Comets in context. Some Thoughts on Bayle's Pensées diverses". In: BOTS, Hans/VAN BUNGE, Wiep. Pierre Bayle (1647-1706), Le philosophe de Rotterdam: philosophy, religion and reception. Brill: Leiden/ Boston, 2008, p. 51-68.

MCKENNA, A.; MOREAU, P-F. Libertinage et philosophie au XVIIe siècle. Saint-Étienne: Presses Universitaires de Saint-Étienne, 2002.

MORI, G. Bayle philosophe. Paris: Honoré Champion, 1999.

PLATÃ̃. A República. Trad. e org. de J. Guinsburg. São Paulo: Perspectiva, 2006.

Recebido em: 21/08/2014

Aprovado para publicação em: 11/09/2014

\begin{tabular}{|c|c|c|c|c|c|}
\hline intuitio & $\begin{array}{c}\text { ISSN } \\
1983-4012\end{array}$ & Porto Alegre & Vol.7- $\mathrm{N}^{\mathrm{o}} .2$ & $\begin{array}{c}\text { Novembro } \\
2014\end{array}$ & p. 172-183 \\
\hline
\end{tabular}

